RECENT MARINE SEDIMENTS OF CARMEL

BAY, CALIFORNIA

Lee Scott Carter 


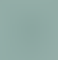




\section{NAVAL POSTGRADUATE SCHOOL Monterey, California}
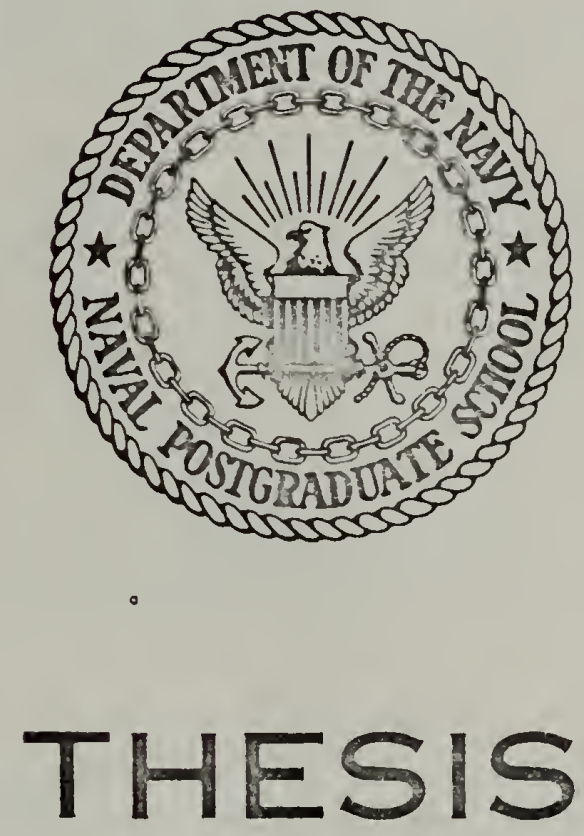

RECENT MARINE SEDIMENTS

of

CARMEL BAY, CALIFORNIA

by

Lee Scott Carter

Thesis Advisor:

R. S. Andrews

December 1971

Approved for public release; distribution unlimited. 



\title{
Recent Marine Sediments
}

of

Carmel Bay, California

by

Lee Scott Carter

Lieutenant, United States Navy

B.S., Naval Postgraduate School, 1970

Submitted in partial fulfillment of the requirements for the degree of

MASTER OF SCIENCE IN OCEANOGRAPHY

\author{
from the \\ NAVAL POSTGRADUATE SCHOOL \\ December 1971
}





\section{ABSTRACT}

Fifty-six sediment samples were collected within Carmel Bay for textural analysis to determine their statistical properties. The sediments found within the Carmel Submarine Canyon consist, for the most part, of poorly to very poorly sorted very fine sand and coarse silt. The shelf area surrounding the canyon is primarily comprised of moderately to very poorly sorted sand, with a small area of very poorly sorted gravel in the northeastern section of the Bay. Consideration of textural parameters such as mean size, standard deviation, and skewness suggest that the sediments of the Bay are under the influence of a dynamic sediment transport mechanism. The Bay appears to be a sedimentary system primarily isolated from adjacent coastal sediment sources, with the major sources of sedimentary deposits being terrigeneous debris from the Carmel River, erosion and weathering of the local coastline and offshore rocks by wave and weather, and the shells and tests of numerous calcareous marine organisms. Movement of sediments by slumping and gravity sliding down the Carmel Submarine Canyon appears to be the only form of sediment removal within the Bay. 

I. INTRODUCTION

A. DESCRIPTION OF CARMEL BAY

B. REGIONAL GEOLOGY

C. BATHYMETRY

D. GENERAL OCEANOGRAPHY

II. SAMPLE COLLECTION

II . SAMPLE ANALYSIS

A. MECHANICAL ANALYSIS PROCEDURE _......... 17

B. COMPUTER ANALYSIS OF RAW DATA _......... 18

IV. PRESENTATION OF DATA

A. TEXTURE OF SEDIMENTS

1. Mean Grain-Size

2. Standard Deviation _....... 25

3. Skewness

B. SHELL CONTENT

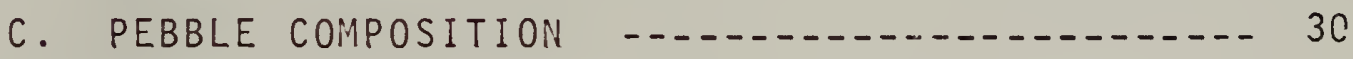

V. DISCUSSION AND INTERPRETATION

A. SEDIMENT DISTRIBUTION PATTERN $\ldots \ldots \ldots$

B. SEDIMENT SOURCES AND SINKS _........ 35

VI. SUMMARY AND CONCLUSIONS

VII. SUGGESTIONS FOR FURTHER STUDIES _... 40 APPENDIX A: Computer Data Card Formats -......... 41

SAMPLE OF COMPUTER OUTPUT _... 42

COMPUTER PROGRAM 

REFERENCES CITED INITIAL DISTRIBUTION LIST FORM $D$ DD 1473 



\section{LIST OF TABLES}

I. Carmel Bay Sample Locations, Sand-Silt-Clay Relationships, and Size Statistics _.................. 21

II. Estimates of Sample Shell Content 29 



\section{LIST OF FIGURES}

Figure

Page

1. Location of Carmel Bay, California -..... 9

2. Carmel Bay Bathymetry _...................... 10

3. Carmel Bay Sediment Sample Locations ....... 16

4. Tertiary Diagram: Sand-Silt-Gravel

Relationships

5. Standard Deviation as a Function of Mean Grain Size - 26

6. Skewness as a Function of Mean Grain Size -- 28

7. Sediment Mean Grain-Size Distribution _.... 32

8. Sediment Standard Deviation Distribution -.- 33

9. Sediment Shell Content 



\section{ACKNOWLEDGMENTS}

The author is deeply indebted to Dr. Robert S. Andrews of the Department of Oceanography, Naval Postgraduate School, Monterey, California for his assistance. Assistance in the collection and processing of samples is gratefully acknowledged from Lcdr. Charles K. Roberts, USN; Lt. Ralph A. Zardeskas, USN; Lt. John P. Simpson, USN; Mr. Jack C. Mellor; Mr. Lawrence Leopold; Miss Norma Tatum; Miss Theodora Cristobel; Mrs. Cynthia J. Carter; and the crews of the Naval Postgraduate School 63-foot Hydrographic Research Vessel and USNS BARTLETT (T-AGOR-13). Grateful acknowledgment is also made to Miss Sharon D. Raney of the W. R. Church Computer Center at the Naval Postgraduate School for her preparation of the computer program for sediment size analysis.

Partial funding for this study was provided to Dr. Andrews through the Naval Postgraduate School Research Foundation under an Office of Naval Research contract. 



\section{INTRODUCTION}

The objective of this study was to describe the distribution of the recent marine sediments of Carmel Bay, California. To accomplish this objective, 52 grab samples and 1 gravity core were collected with in the Bay.

Among the previous studies of the marine sediments of Carme 1 Bay are two M.S. theses by students of the Naval Postgraduate School; one on the sediments at the head of the Carmel Submarine Canyon [Wallin, 1968], and one on a heavy mineral investigation of Carmel Bay beach sands [Griffin, 1969]. Judge [1970] reported on one sample taken at Carmel River Beach and analyzed for size distribution and heavy mineral content.

\section{A. DESCRIPTIOIN OF CARMEL BAY}

Carmel Bay is located on the Coast of California approximately $160 \mathrm{~km}$ south of the entrance to San Francisco Bay (Fig. 1) and $9 \mathrm{~km}$ south of the southern extreme of Monterey Bay. The Bay is generally rectangular in shape with dimensions of about $4.3 \mathrm{~km}$ in the north-south direction and $3.6 \mathrm{~km}$ in the east-west direction (Fig. 2).

The Bay is bounded on the north by the community of Pebble Beach, on the east by the City of Carmel, and on the south by Point Lobos State Reserve.

The Bay drains approximately 670 square $\mathrm{km}$ of watershed through two watercourses, the Carmel River and San Jose Creek (Fig. 2) [California State Department of Water Resources, 1969]. 



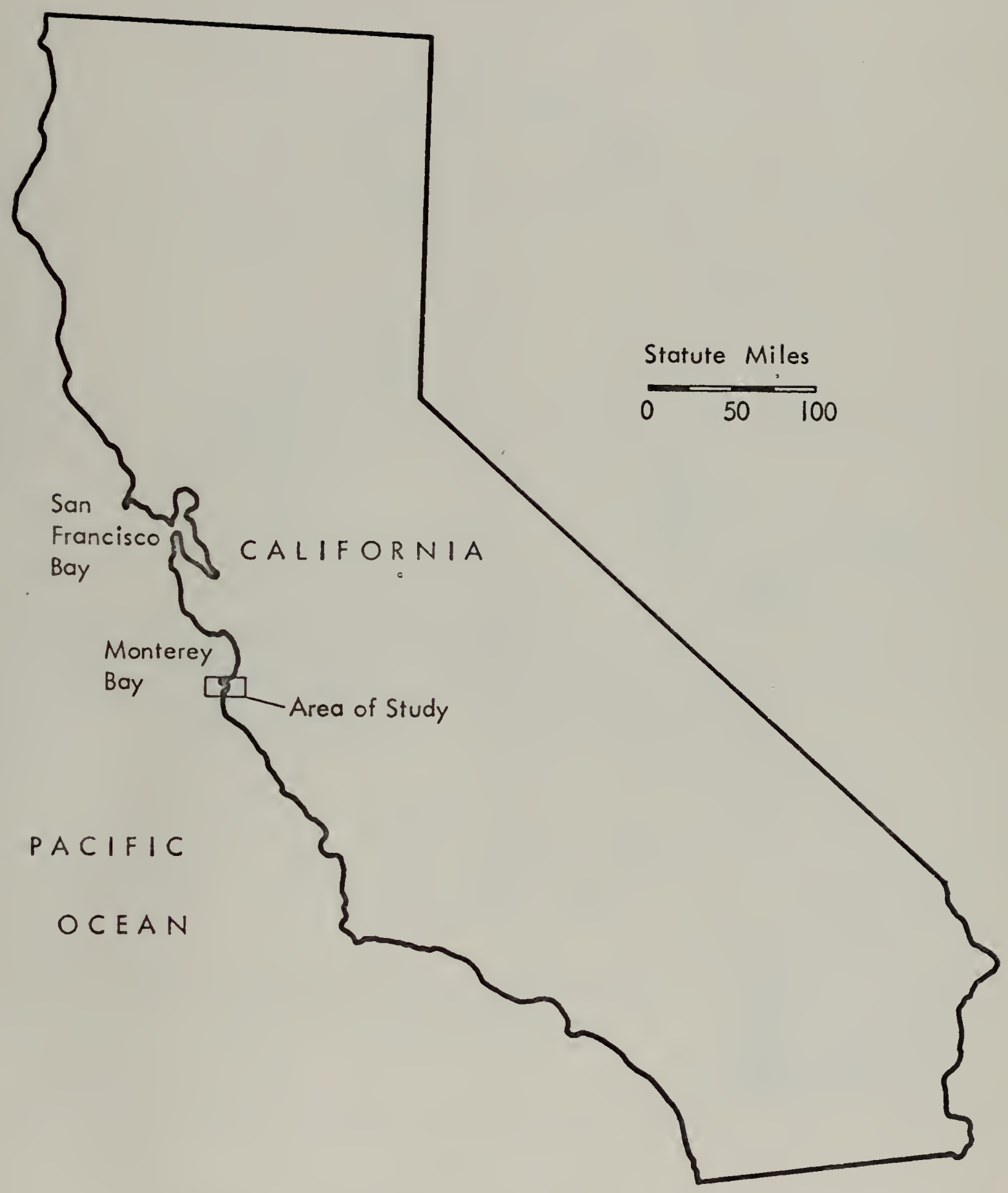

Figure 1.. Location of Carmel Bay, California. 



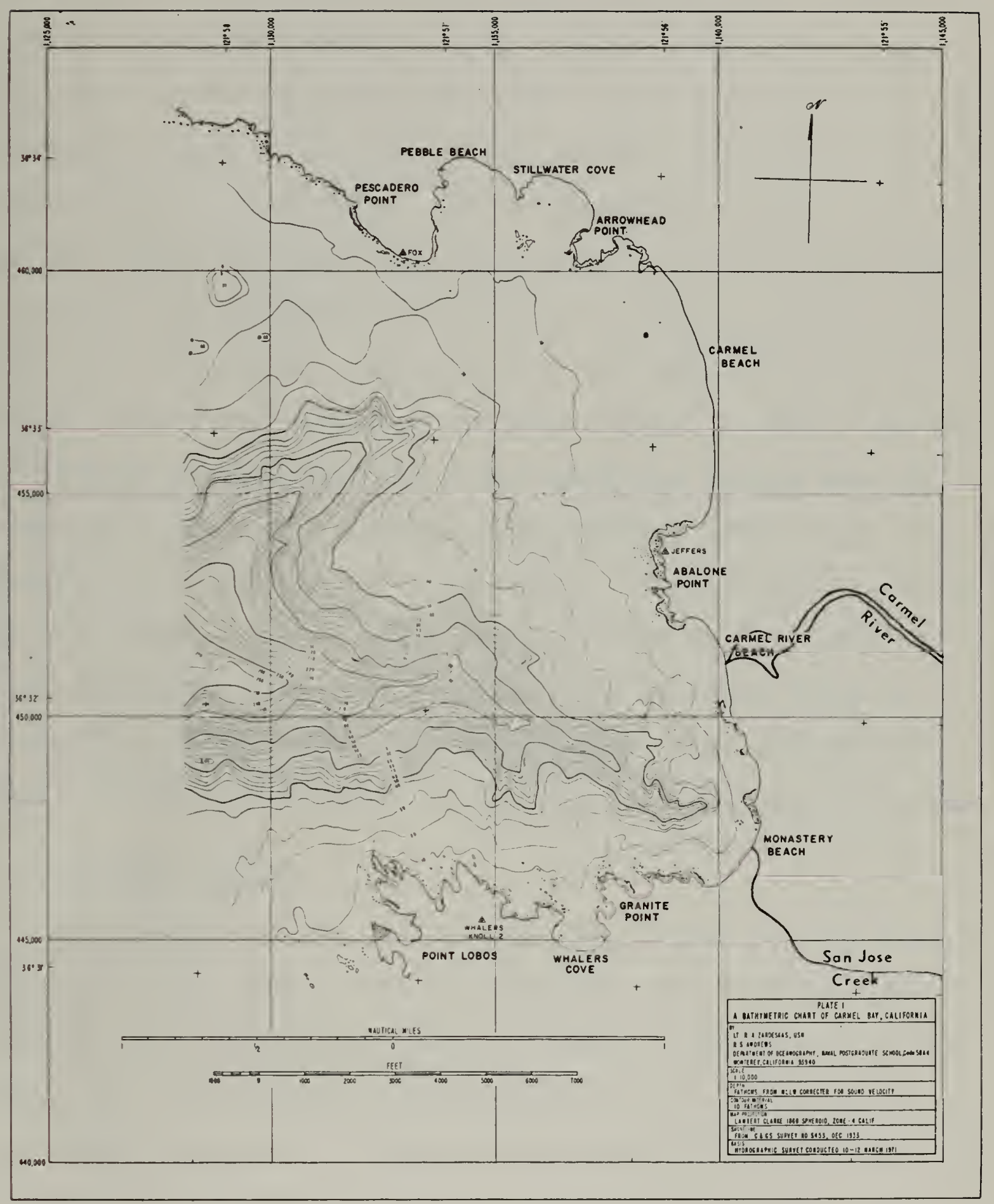

Figure 2. Carme1 Bay Bathymetry. (After Zardeskas, 1971) 

The discharge from the Carmel River is quite seasonal with heavy runoff during the rainy winter months and virtually no runoff during the summer and fall months. During the summer and fall months the beach berm crest closes off the river mouth, forming a small fresh-water lagoon on the backshore. After the start of the rainy season, and as conditions dictate, the mouth of the river is forced open by bulldozer to reduce the danger of severe flood damage if the river is unable to breach the berm crest by itself. Normally this forced opening of the mouth is required only once or twice a year; however, during the winter of 1966-1967 the river mouth was forced open 25 times by crews from the Point Lobos Reserve State Park [Mr. Donald Rich, personal communication]. This breeching results in the carrying off of large amounts of sedimentary debris into the ocean. The flow of water from San Jose creek is normally so meager that very little water ever reaches the shore of the Bay except during periods of heavy winter rains.

\section{B. REGIONAL GEOLOGY}

The geology of the area surrounding Carmel Bay has been studied in some depth by Lawson [1893], Beal [1915], Bowen [1965], and Nili-Esfahani [1965]. Bowen's publication is the basis for much of the following information.

There are several different formations associated with the geology of Carmel Bay and its associated watersheds. These watersheds constitute an important source of supply of fresh materials for the sediments of the Bay. The most conspicuous of the rocks is the Santa Lucia porphyritic biotite 

granodiorite. This formation was intruded deep into the Paleozoic Sur Series early in the Cretaceous period. Through uplift and erosion much of the Sur series was removed, leaving only the granodiorite. Subsequent depression presented the opportunity for further marine deposition. During the Paleocene age the Carmelo Series, consisting of interlayed beds of sandstones, siltstones and conglomerates, was deposited.

The Middle Miocene Chamisal Formation overlays the Carmelo east of the Bay and this is in turn overlain by Middle Miocene iddingsite andesite lava which outcrops at five or six points around the Bay. The lava is in turn overlain by Middle and Upper Miocene Monterey siliceous shale.

Granodiorite outcrops are found at three points around the shore of the Bay: Pescadero Point, Abalone Point, and Point Lobos. The Carmelo outcrops in the northern area of the Bay in the vicinity of Stillwater Cove and to the south in the vicinity of Whaler's Cove. A massive outcrop of lava exists at Arrowhead Point, with a smaller one appearing to the south of Carme 1 Beach. The remainder of the shoreline consists of the Quaternary sandstones which lie above the Monterey shale, and Recent unconsolidated sand and gravel.

The upper watershed of the Carmel River is composed primarily of Paleozoic metamorphic gneisses of the Sur Series. These metamorphics are an important source of supply of heavy minerals to the sediments and beaches of Carmel Bay. The lower portion of the watershed is comprised primarily of Santa Lucia granodiorite and Tertiary sedimentary rocks 
[California State Department of Water Resources, 1969]. These sedimentary rocks, being generally soft, are subject to intense weathering, and contribute a much greater amount of sedimentary material for transport to the sea than do the much harder crystalline metamorphic and granitic rocks of the area. San Jose Creek follows a path that takes it through Monterey shale and Santa Lucia granodiorite.

\section{BATHYMETRY}

A complete bathymetric survey of Carmel Bay was made in March of 1971 (Fig. 2). This was the first survey made of the entire Bay which utilized echo-sounding equipment [Zardeskas, 1971]. The current U.S. Coast and Geodetic Survey chart of the Bay (C\&GS 5476) is based on data collected in 1933 utilizing lead line soundings and sextant navigation.

The Bay is transected by the Carmel Submarine Canyon, which has its origin immediately offshore of San Jose creek and its termination where it branches with the Monterey Submarine Canyon some $21 \mathrm{~km}$ to the northwest of the mouth of San Jose creek. The bed of San Jose Creek, which flows through a narrow $V$-shaped canyon throughout its 10 miles of length, tends to follow the Blue Rock Fault [Griffin, 1969] and appears to be a direct landward extension of the Carmel Submarine Canyon. Carme l Canyon is similarly a narrow $V$-shaped canyon cut into granodiorite [Shepard, 1963].

The area to the south of the Carmel Submarine Canyon axis is bounded by small pocket beaches, rocky cliffs and large offshore rocks, both submerged and exposed. Numerous ravines 

traverse the nearshore shelf and intersect the edge of the canyon at a water depth of about $50 \mathrm{fm}$.

The coastline to the north of the canyon axis is also very rocky, with large offshore rocks and small pocket beaches. The bottom has a much gentler slope than the area to the south, and, as in the south, reaches a depth of approximately $50 \mathrm{fm}$ before rapidly dropping off into the canyon. The eastern side of the Bay is bounded by three sandy beaches: San Jose Beach (sometimes called Monastery Beach), Carmel River Beach, and Carmel Beach (Fig. 2), each separated from the next by a rugged outcrop of granodiorite ( $p$ lus some Miocene lava between Carmel River Beach and Carmel Beach). The head of the canyon is located about $200 \mathrm{~m}$ offshore from San Jose Beach (Monastery Beach) with the rim of the canyon occurring at depths of $7 \mathrm{fm}$ to $10 \mathrm{fm}[$ Wallin, 1968, p. 17]. One major branch of the canyon incises the northern shelf of the Bay.

\section{GENERAL OCEANOGRAPHY}

References in recent literature concerning the physical oceanographic properties of Carme 1 Bay are noticeably lacking. Records of measurements of the currents and thermal structure of the Bay are virtually nonexistent.

The tides in the Bay are of the mixed type characteristic of the Pacific Coast of the United States [Sverdrup, Johnson, and Fleming, 1942I. The diurnal difference between mean lower low water and mean higher high water is 5.2 feet [U.S. Coast and Geodetic Survey, 1971]. 



\section{SAMPLE COLLECTION}

Samples were collected by ship, using a Shipek grab sampler and a 2.75-inch outside diameter, 700-1b total weight gravity corer. Fifty-two grab samples and one gravity core (Station C-1) were collected during the period from April to June 1971 (Fig. 3). Stations were located by measuring the horizontal angles between known landmarks around the Bay utilizing a sextant. Sample depth was obtained by fathometer, or by wire depth when electronic soundings were not available.

It was not possible to occupy some stations in the vicinity of Carmel Beach and Pescadero Point due to heavy concentrations of kelp (Macrocystis pryifera) in these areas. Several sample collections were attempted in the kelp-free areas off of Pescadero Point, but only a few rock dwelling tunicates and gastropods were collected, suggesting a rocky bottom.

Grab samples were placed in double plastic bags and refrigerated until processed. The gravity core in its plastic liner was capped and sealed and stored in a cool, dark location in an upright position until cut and processed. 



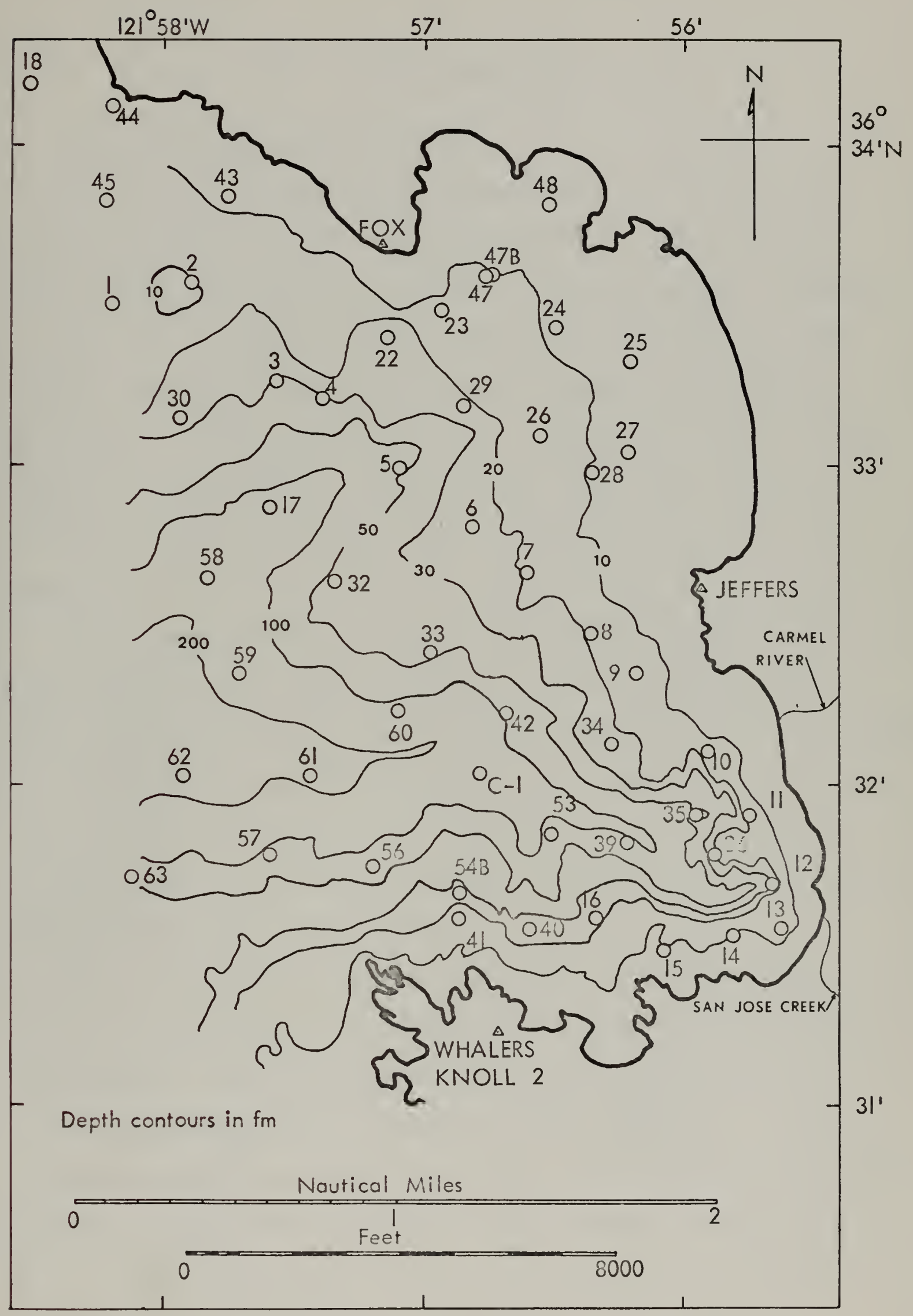

Figure 3. Carmel Bay Sediment Sample Locations. 



\section{SAMPLE ANALYSIS}

A. MECHANICAL ANALYSIS PROCEDURE

Grain-size analyses were conducted in accordance with

the procedures outlined in Krumbein and Pettijohn [1938]. Grab samples were split to obtain a representative subsample of about $60 \mathrm{~g}$. Three of the grab samples (Samples 10, 26, and 47) contained a large number of large pebbles, making splitting of the sample difficult. Therefore, each of these samples was analyzed in its entirety. The core was split lengthwise into two equal halves and four subsamples were taken.

All subsamples were washed in distilled water to desalt. Each subsample was then allowed to settle and the excess water decanted off. The subsample was then wet sieved through a 4.00 screen to separate the sand-and gravel-size fractions from the silt-and clay-size fractions. The fine fraction $(>4.0 \emptyset)$ was collected in a 1000-ml sedimentation cylinder and the coarse fraction was dried.

The dried coarse fraction was then size graded with screens according to the Wentworth scale using phi notation $[$ Folk, 1968]. This was accomplished by sieving at a $0.5 \emptyset$ interval through 3 -inch diameter sieves shaken on a Ro-tap automatic shaking machine for $10-$ min. The three large samples (Samples 10, 26, and 47) were sieved through 8-inch screens. The fraction retained on each sieve was weighed to the nearest 

$0.1 \mathrm{mg}$ and the $3.0 \emptyset, 3.5 \emptyset$, and $4.0 \emptyset$ fractions were placed in vials for later microscopic analysis.

The fraction finer than 4.00 (pan fraction) obtained during dry sieving was next added to the 1000-ml cylinder containing the fine fraction obtained by wet sieving. A peptizing agent (Calgon) was then added and a pipette analys is was performed on each subsample with a 0.50 interval. Wadell's correction of Stoke's law was used to determine the setting velocities of the different sized particles. Each 20-ml pipette aliquot was dried and weighed to the nearest $0.1 \mathrm{mg}$, taking into account the weight of the dried peptizer in the sample.

Those silt-clay samples which obviously contained less than $5 \%$ of the total sample weight were not analyzed using the pipette method, but were instead transferred to a 50-m 1 beaker, dried, and weighed directly to check this assumption.

\section{B. COMPUTER ANALYSIS OF RAW DATA}

Statistical parameters for describing the size distribution in each sample were calculated on an IBM 360 computer. A size analysis computer program prepared by W. R. Anikouchine [Dinger, 1970, p. 31] was slightly modified to provide a printed output of phi sizes at the 5 th, 16 th, $25 \mathrm{th}, 50 \mathrm{th}, 75 \mathrm{th}, 84 \mathrm{th}$, and 95 th percentile levels, gravel-sand-silt-clay relationships, plus Trask values, Inman values, and Folk and Ward values [Collias, et a 1., 1963], using both linear and four point interpolation methods. A copy of the computer program 

and a sample of the computer output is listed at the end of this thesis. Computer data card formats are listed in Appendix A. 



\section{PRESENTATION OF DATA}

\section{A. TEXTURE OF SEDIMENTS}

The tabulated results of the computer size analysis are presented for the gravel, sand, silt, and clay percentages and the linear interpolation of the Folk and Ward statistics (Table I). While the term "gravel" does not appear in Wentworth size classifications, it is commonly used to represent the combination of granules and pebbles; i.e., particles coarser than -1.00 and finer than -6.00 [Folk, 1968].

1. Mean Grain-Size

The mean grain-size of the sediments of Carmel Bay covered a wide range of values from $-3.34 \emptyset$ (Sample 47) to 4.719 (Sample 59).

Sand-silt-clay-gravel relationships were plotted on a sand-silt-gravel diagram similar to that devised by Shepard [Collias, et a $] ., 1963, p .33]$. The sand-silt-gravel diagram (Fig. 4) is one face of a tetrahedron used by Krumbein and Sloss [1963, p. 158] to plot sand-silt-clay-gravel relationships. All of the Carmel Bay samples contained less than $20 \%$ clay, thus allowing the samples to be plotted on the sand-siltgravel face of the tetrahedron. The samples ranged in texture from gravel (Sample 47) to sandy-silt (Samples $35,42,53,56$, 57 , 59, and 61) (Fig. 4), with 28 of the 56 samples containing more than $75 \%$ sand. The mean grain size was generally larger near shore and decreased out toward and into the submarine 



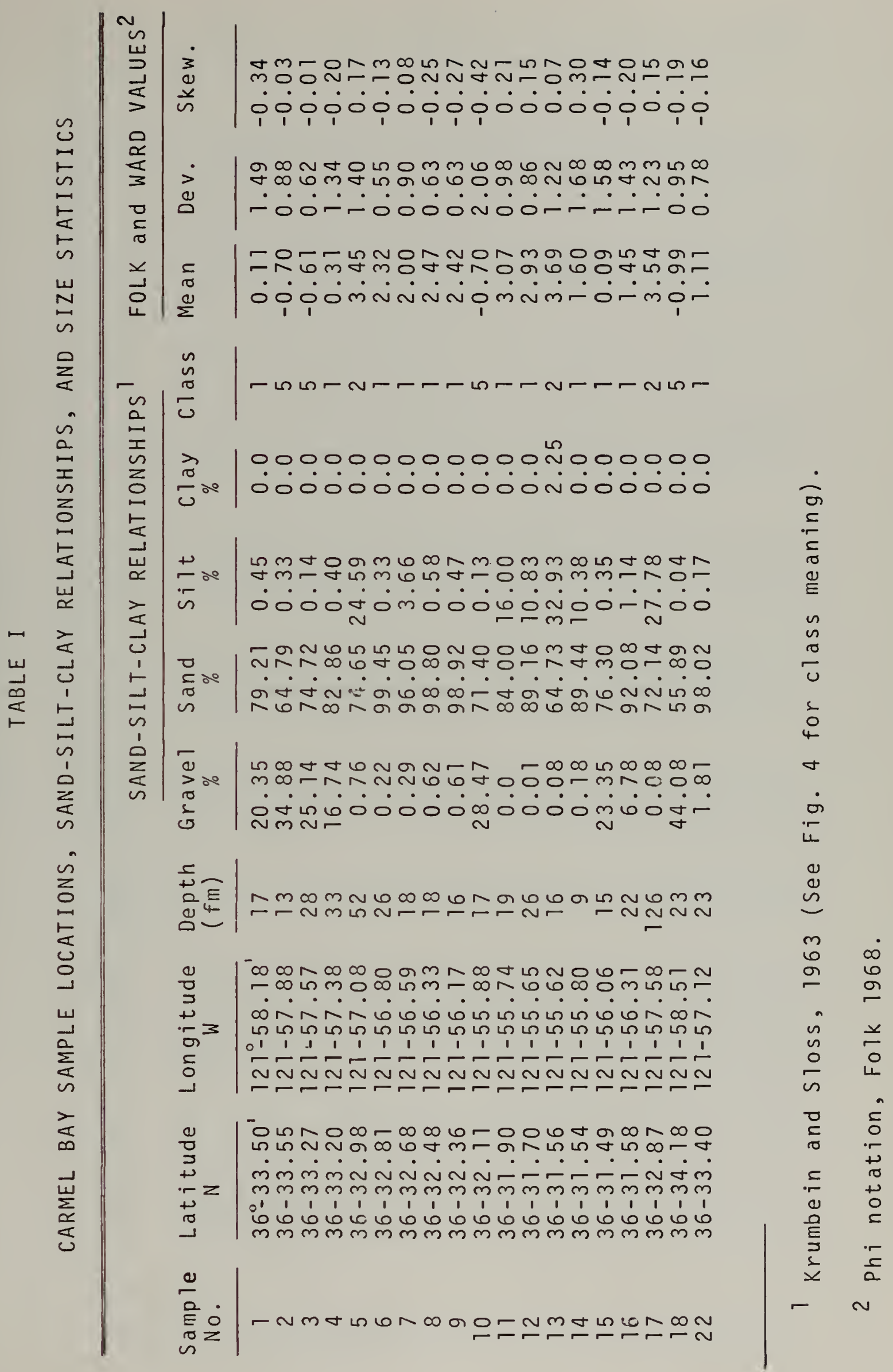



$\infty \infty N+L N N O 0 m \infty \mathrm{m}$ -

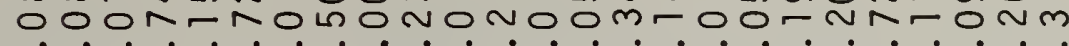
-

L N $666 \mathrm{~m} \omega \mathrm{mLLF}+4$ \%

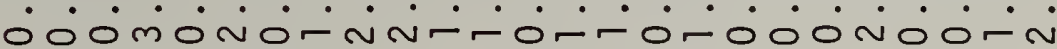

$m m N \omega N N N$ m

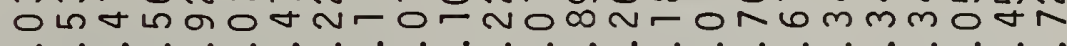

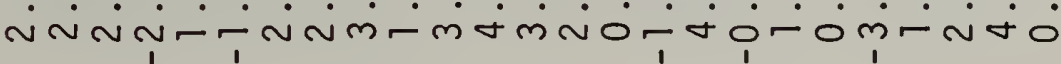
-ーー $00000000 \stackrel{\infty}{0} 0$ mo 00000000000

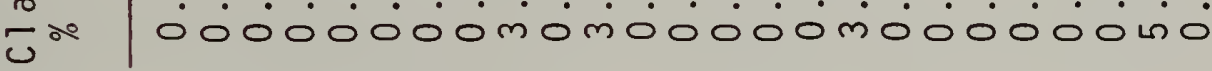

G NDNRINMMNM

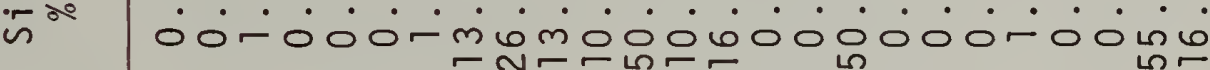

ర

o

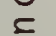
N-N

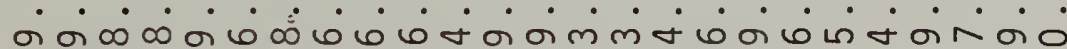

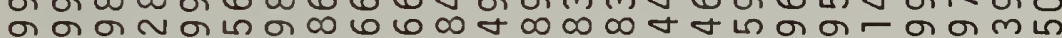

$\sum_{\pi}^{\infty}$

- -

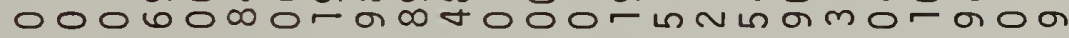

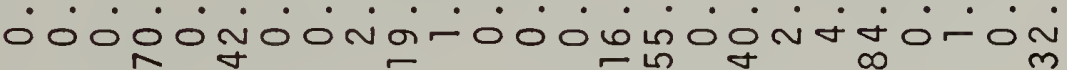

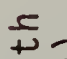

辰

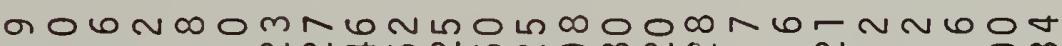
I-

0
0
2
+1
0
0
0
0

-

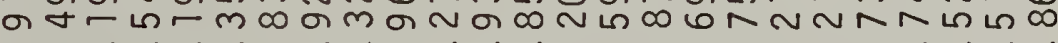
•

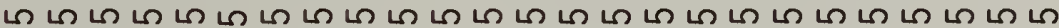

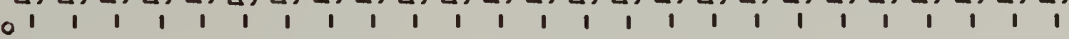

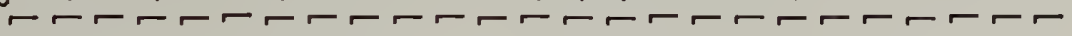

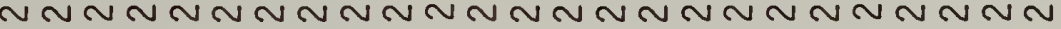

NmNGLN オ

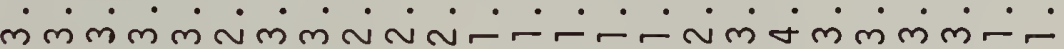

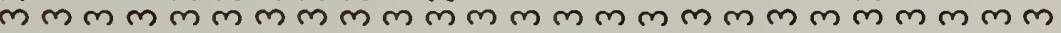

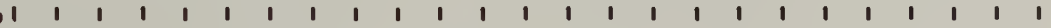
m $\frac{0}{\infty}$
$\stackrel{0}{E}$
$\sim$

$m+L \omega N \infty$ G NNNNNNNmmm m m m 


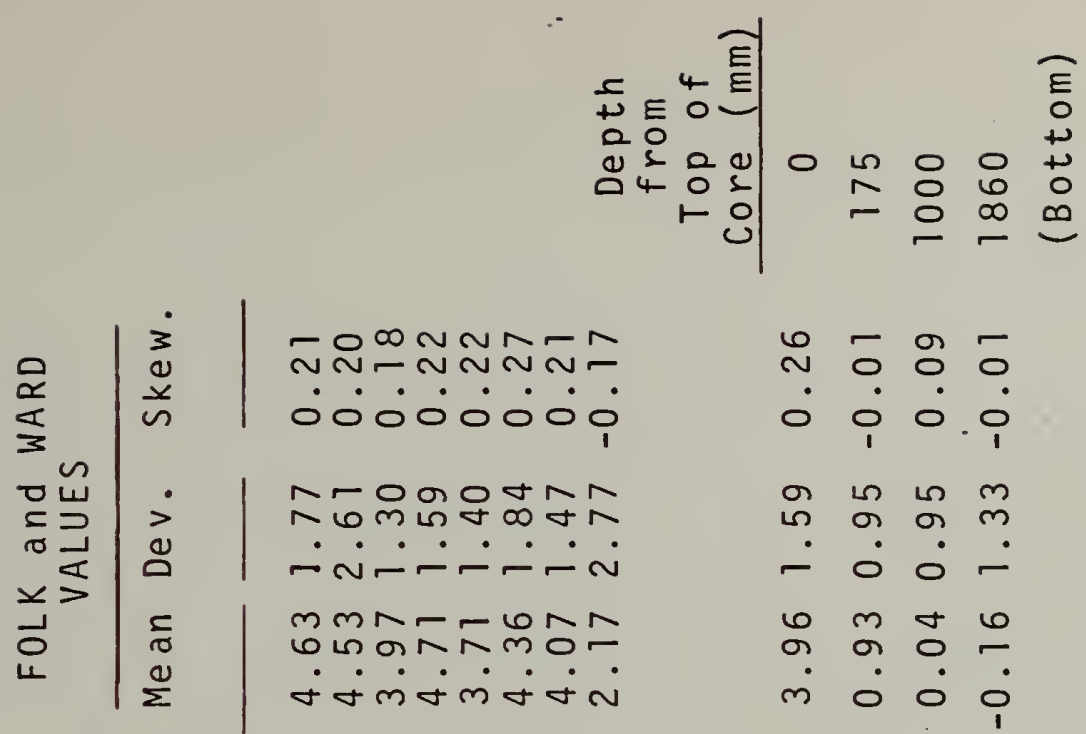

$\begin{array}{llll}0 & 0 & 0 & 0 \\ 0 & 0 & 0 & 0 \\ 0 & 0 & 0 & 0 \\ 0 & 1 & 0 & m \\ m & 0 & 0 & m \\ - & 0 & 0 & - \\ 0 & m & 0 & 0 \\ 0 & 0 & 0 & - \\ m & 0 & 0 & 0\end{array}$

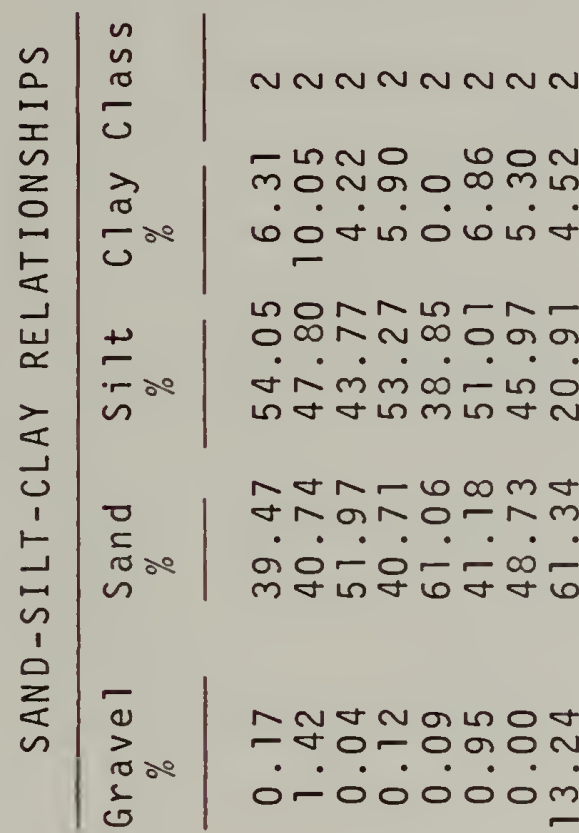

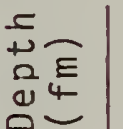

$6 \div 0 \infty \square \infty 0$ \%

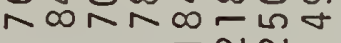
- $-N$

$N \sqcap-1$

in 0 :

a 0 N N

i $\dot{0} \dot{0} \dot{0}$

$\infty N$ a $\infty$

- $\dot{0} \dot{0}$

in o $\infty n$

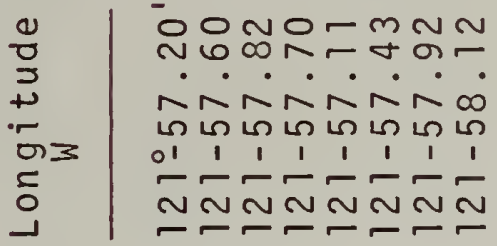

$\begin{array}{ccc}\infty & \infty & \square \\ = & \infty & 0 \\ 0 & \dot{0}\end{array}$

$N N N$

$r N$

or or or

-.

i $\dot{0}$ i

in 10

$\frac{1}{N} \stackrel{1}{\pi} \frac{1}{N}$

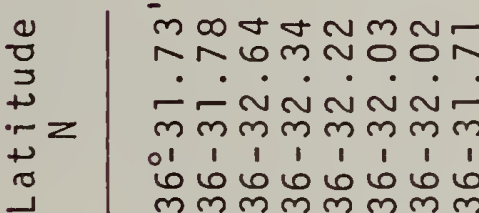

$\pi N N$

000

N $\mathrm{N}$ i

.. $m m m m$

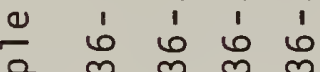

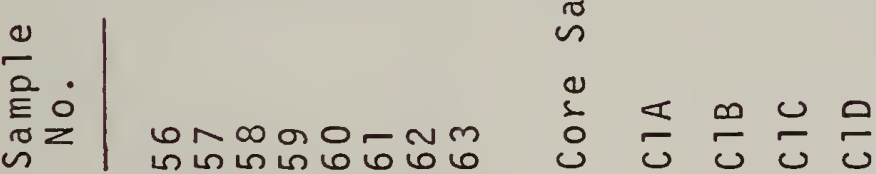





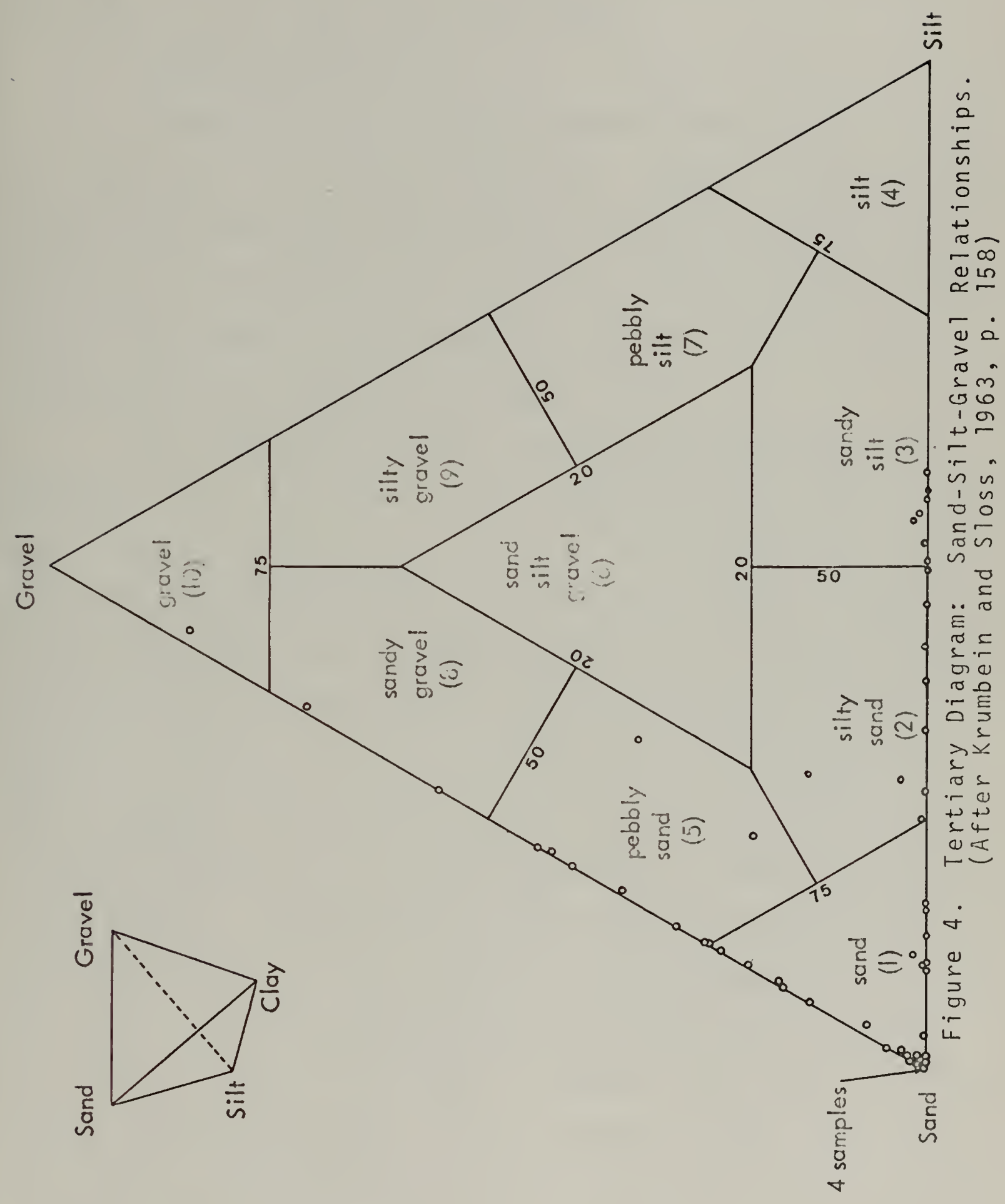



canyon. An offshore area of coarser material was also 10ated in the northeastern portion of the Bay between Fox and Jeffers bench marks (Fig. 3). Core C-l showed a marked increase in mean grain-size with depth.

\section{Standard Deviation}

Standard deviation values ranged from a value of $0.43 \emptyset$ for Sample $47 \mathrm{~B}$ to $3.34 \varnothing$ for Sample 26. Sample $47 \mathrm{~B}$ was the only sample collected within the Bay that was well sorted. Nine samples were classified as very poorly sorted with the remainder of the samples being approximately evenly divided between moderately sorted and poorly sorted.

Folk and Ward's [1957] statistical analysis of the sediments of a river bar in Texas revealed that a plot of mean grain-size vs. standard deviation for their group of samples showed a definite trend line of sinusoidal nature. Comparison of the Carmel Bay plot of mean grain-size vs. standard deviation (Fig. 5) with the results obtained by Folk and Ward (dashed line on plot) shows a marked similarity between the two, suggesting the sediments of the Bay are under the influence of some form of dynamic transport. Some anomalies do exist however. These anomalies may possibly be explained by the fact that all of the anomalous samples (Samples 2, 3, 18, $32,33,41,43,47,54 B, 57$, and 63) except one (Sample 26) are composed primarily of shell fragments and other calcareous marine organism remains, and are located in water less than $50 \mathrm{fm}$ deep. Differences in density and grain shape of these samples compared to those of mineral strains could well cause a different type of sorting behavior. 



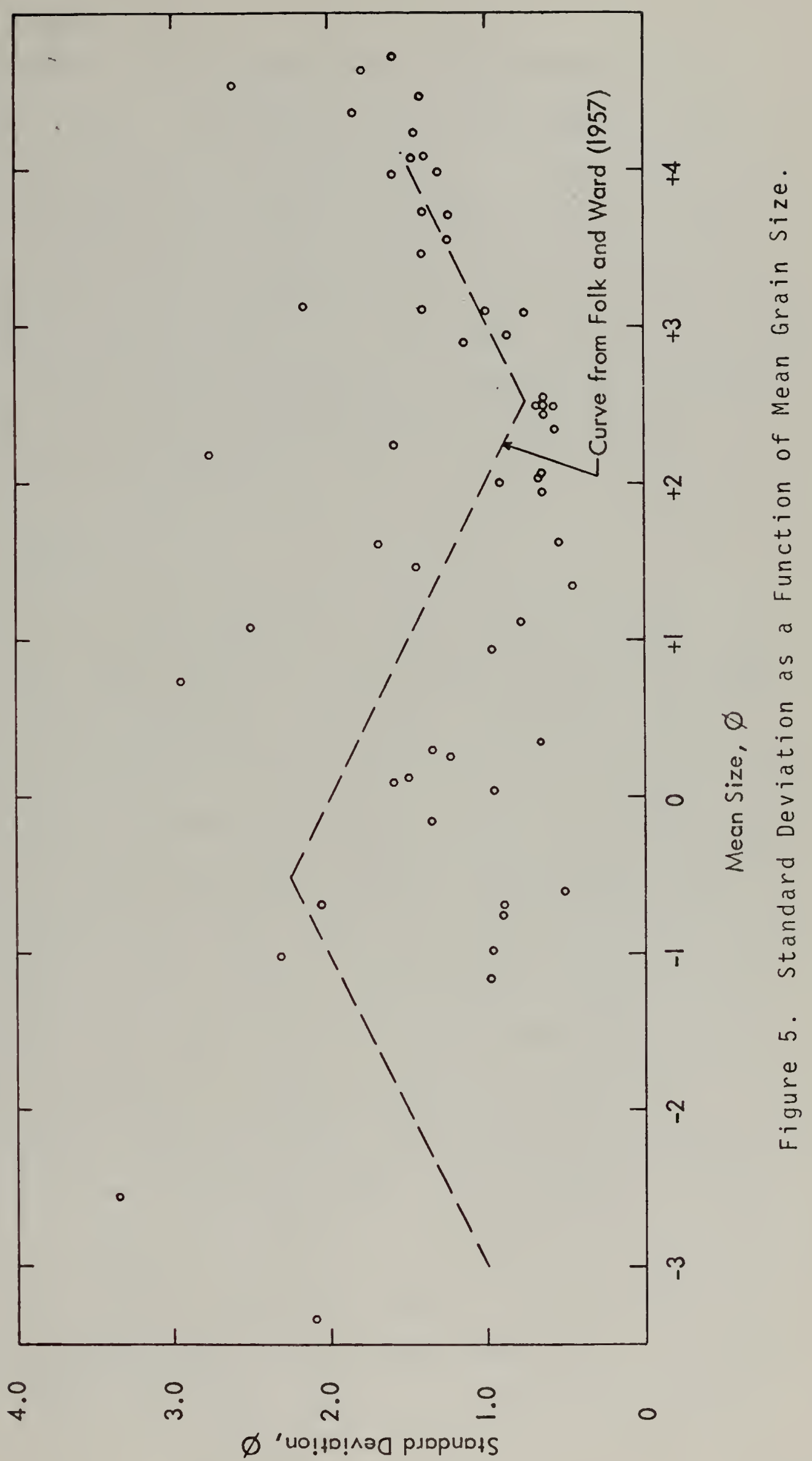





\section{Skewness}

Skewness values ranged from t0.74 (Sample 26) to -0.72 (Sample 28). The samples were approximately evenly divided between positively and negatively skewed (Fig. 6), and tended to follow the trend obtained by Folk and Ward (dashed line on plot) in their river bar study. The departures of the skewness values for Carmel Bay samples from those of Folk and Ward may be explained by recognizing the difference between river and continental shelf depositional environments and sources.

\section{B. SHELL CONTENT}

Visual inspection was made of the $0.0 \emptyset$ and larger fractions of each sample and an estimate made of the percentage of shells, shell fragments, worm tubes, bryozoan colonies, corals, and echinoderm spines contained in each sample (Table II). All of these constituents were grouped under the heading of "shel1s." These estimates revealed approximately $20 \%$ of the samples contained $100 \%$ "shells" in their $0.0 \emptyset$ and coarser fractions, $25 \%$ of the samples contained $50 \%$ to $99 \%$ "she $11 \mathrm{~s}$," $30 \%$ contained $1 \%$ to $49 \%$ "shells," and the remaining $25 \%$ of the samples contained no visible amount of "shells."

Considerable amounts of small particles of vegetable matter (probably kelp) were noted in eight of the samples (Samples 5 , $13,17,58,59,61,62$, and $C-1 A)$. Of additional interest was the fact that Sample 14 contained nine living sand dollars (Dendraster excentricus) when brought aboard ship. No other benthic organisms or their remains were noted within this sample. 



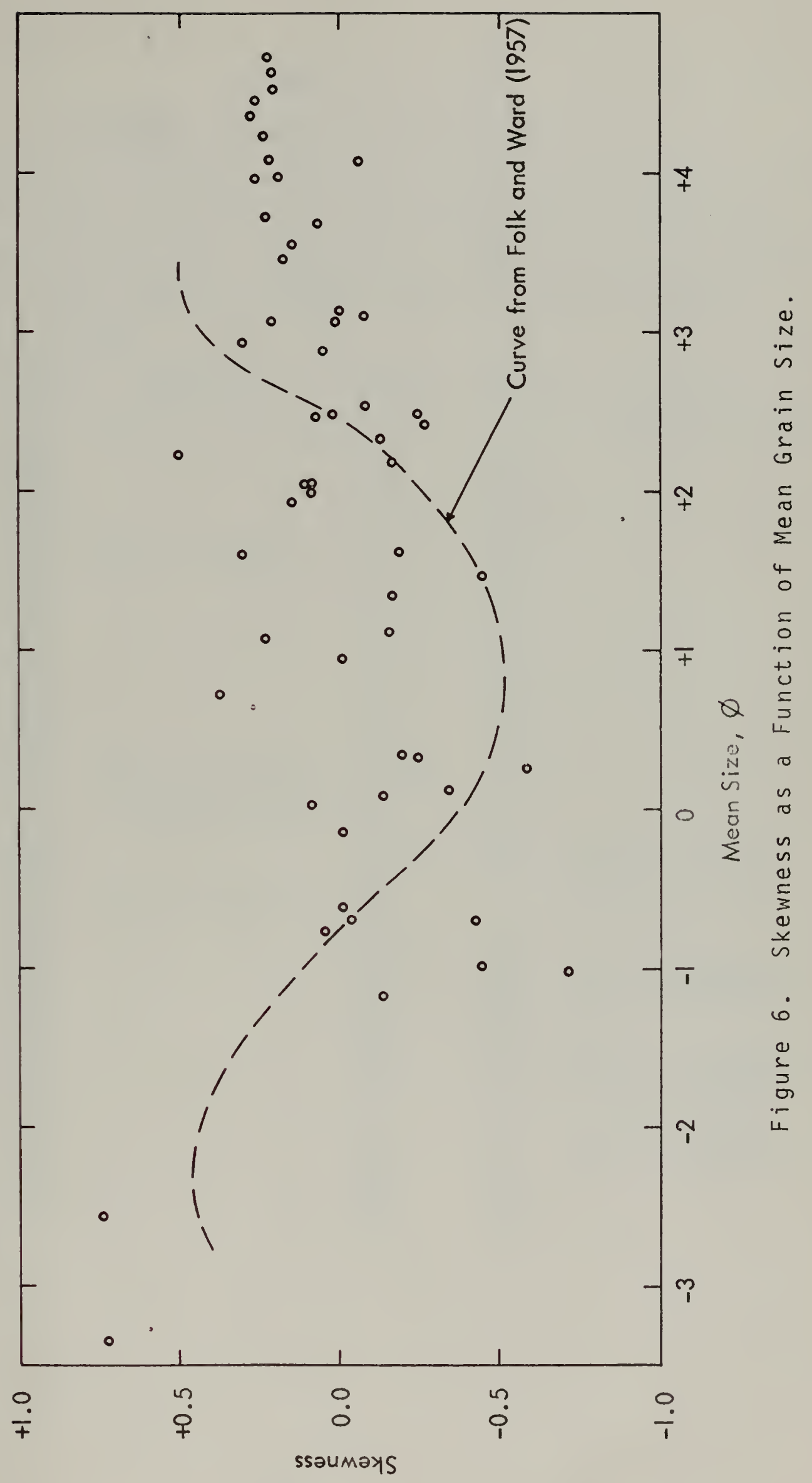





\section{ESTIMATES OF SAMPLE SHELL CONTENT}

Visual observation of the $0.0 \varnothing$ and larger fraction of each sample yielded the following estimates of shells, shell fragments, worm tubes, bryozoan colonies, corals, and echinoderm spines.

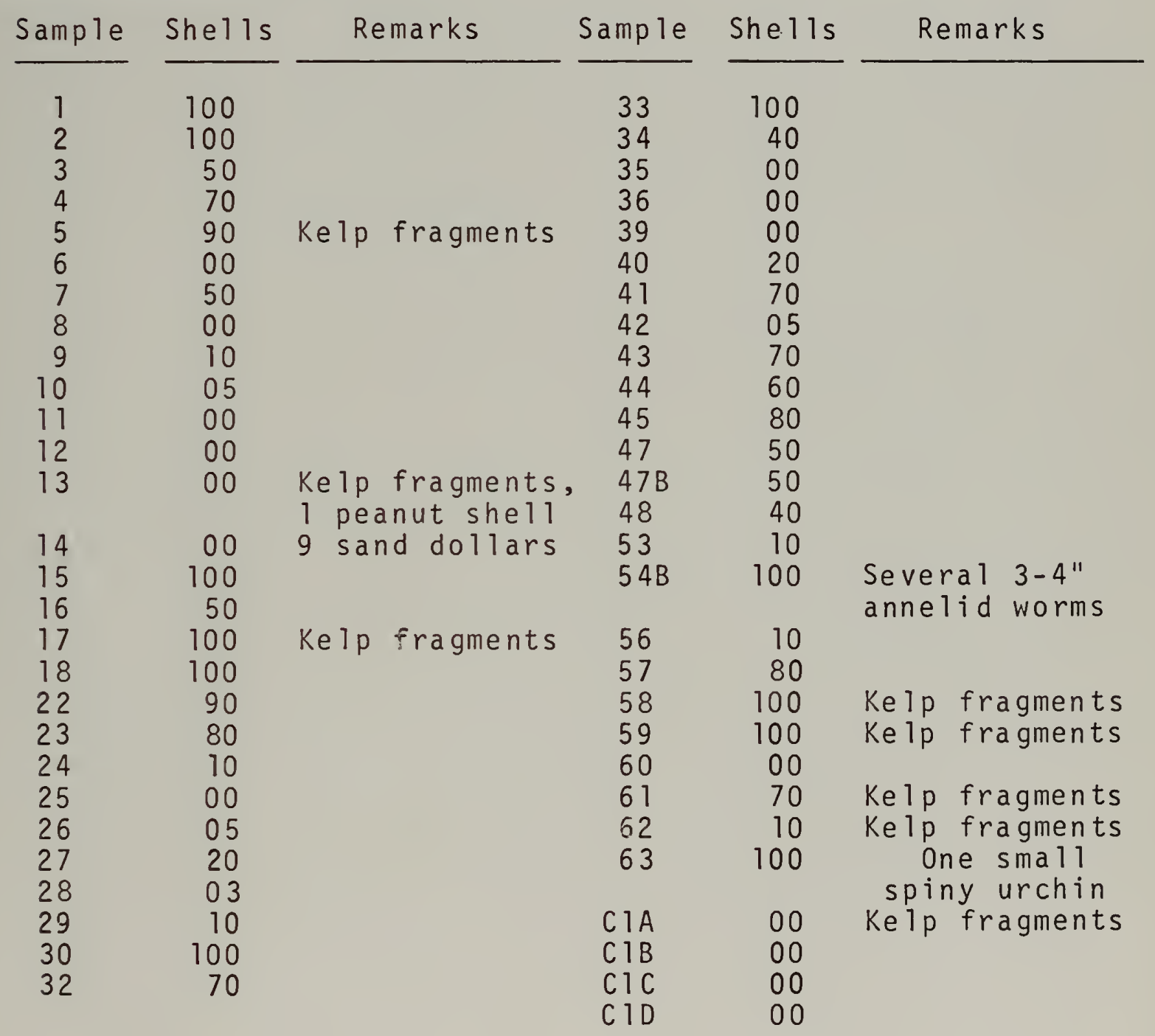





\section{PEBBLE COMPOSITION}

Within the gravel fraction were rock fragments derived from the local shorelines. Samples 4, 26, and 47 contained lava pebbles, probably derived from the lava flows on Arrowhead Point. Granodiorite pebbles were found in Samples $1,4,15,26,28$, and 41 , while pebbles of Monterey shale were found in Sample 10. Sample 26 contained some andesite porphyry pebbles probably derived from the Carmelo. The accumulation of these gravels could represent beach sedimentation during the Pleistocene lowering of sea level as shown by Martin [1964, p. 135]. 



\section{DISCUSSION AND INTERPRETATION}

\section{A. SEDIMENT DISTRIBUTION PATTERN}

The sediment distribution pattern within Carmel Bay can be broken into two separate environments. The sediments around the periphery of the Bay range from gravel to fine sand, while the sediments found within the Carmel Submarine Canyon are almost exclusively very fine sand and coarse silt (Fig. 7). The only exception to this is the deposit of fine sand found within the canyon near its head.

The rocky areas to the north and south of the Bay contain considerable numbers of benthic organisms and the shells and tests of these organisms constitute a significant part of the coarse grained, poorly sorted sediments in these areas. Figure 8 shows the distribution of standard deviation of the sediments and Figure 9 describes the sediment shell distribution. Offshore transport of these shells and tests toward the canyon by currents and wave action has broken their constituent members into smaller and smaller pieces, resulting in a corresponding reduction in mean grain-size with distance from shore.

As might be expected, the area off of the mouth of the Carmel River also displays a concentration of coarse grained, very poorly sorted sediments, composed primarily of terrigenous material. 



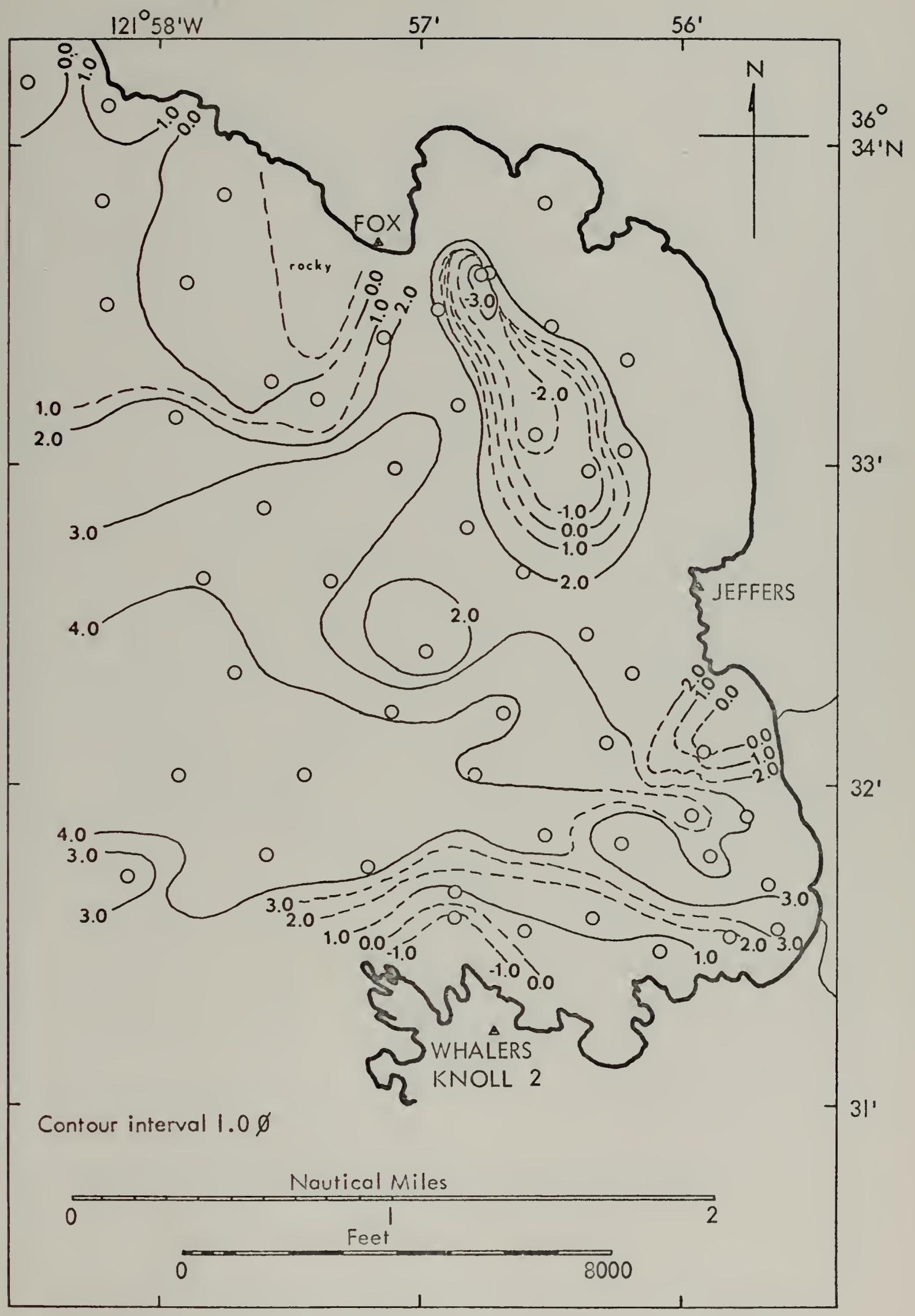

Figure 7. Sediment Mean Grain-Size Distribution. 



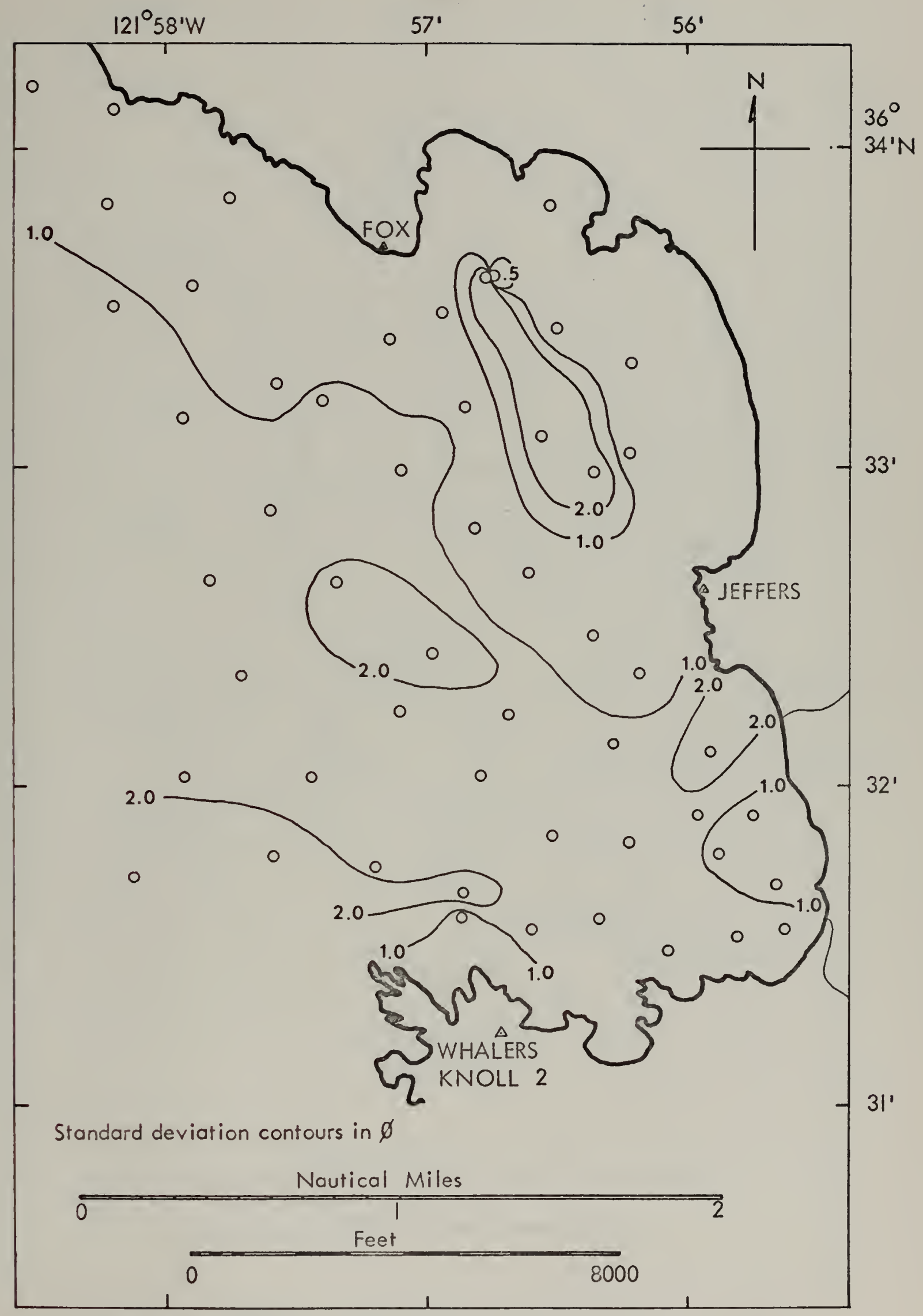

Figure 8. Sediment Standard Deviation Distribution. 



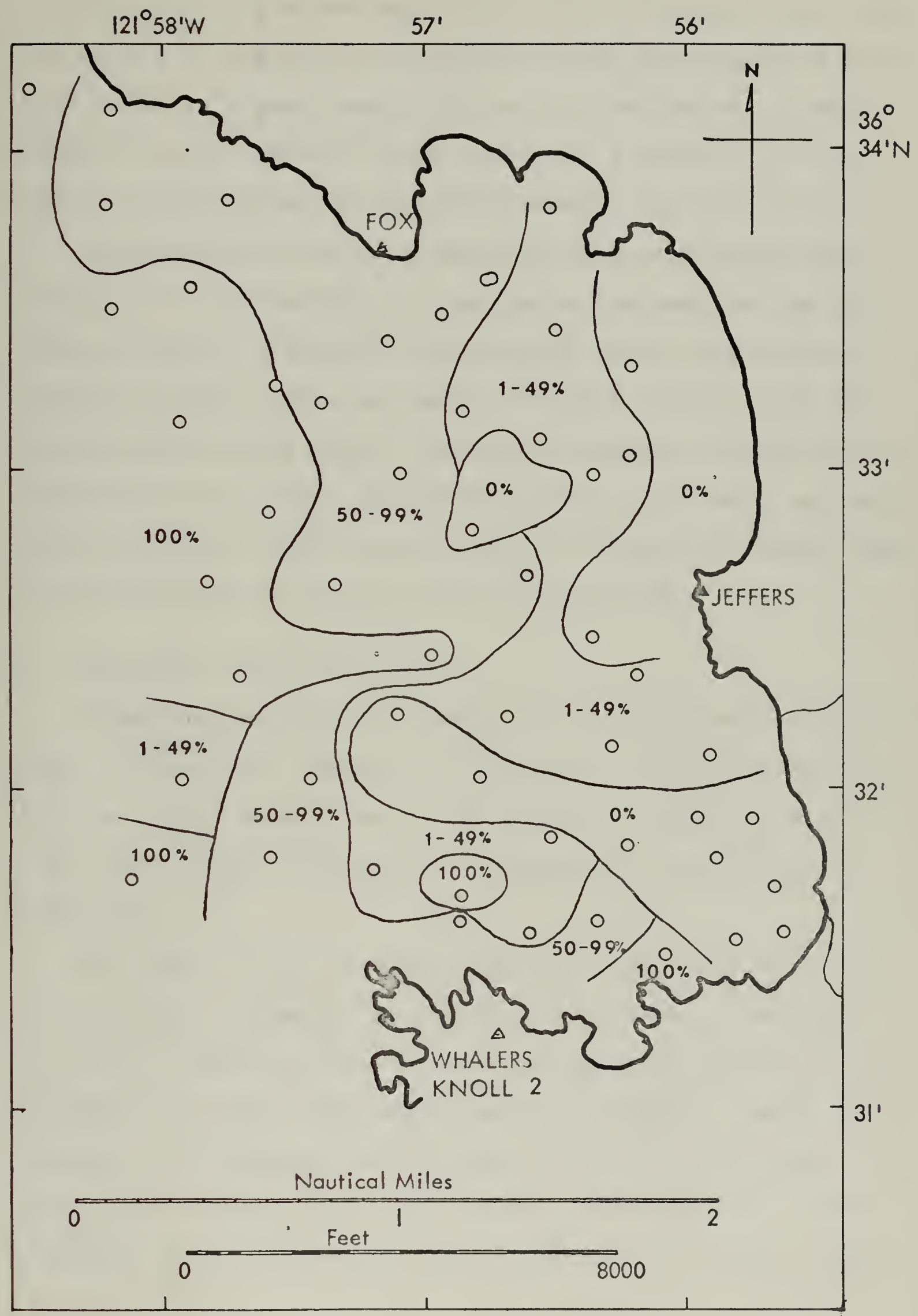

Figure 9. Sediment Shell Content. 

Two anomalous areas appear to exist within the Bay. In the middle of the Bay is a pocket of very poorly sorted coarse sand centered around Sample 33, and in the northeast area, between Fox and Jeffers bench marks, is a deposit of very poorly sorted gravel encompassing Samples 26,28 , and 47 .

A mixed pattern of fine and very fine sand exhibiting moderate to poor sorting is found near the head of the submarine canyon. A detailed description of the sediments in the head of the canyon was made by wallin [1968]. The sediments of the canyon itself consist of poorly sorted very fine sand and coarse silt. The eight samples previously mentioned which contained considerable amounts of vegetable matter were all located at or near the axis of the canyon.

\section{B. SEDIMENT SOURCES AND SINKS}

Carmel Bay represents essentially a closed sedimentary system. The physical nature of Point Lobos, to the south, and Cypress Point, about $1 \mathrm{~km}$ to the north of Pescadero Point, is such that littoral transport of sediments into the Bay is negligible.

The Carmel River is undoubtedly the largest supplier of terrigeneous sediments for the Bay. The river is dormant during the summer and fall, thus contributing nothing to the sedimentary system, but during periods of heavy runoff large amounts of sedimentary debris are carried into the Bay. San Jose creek is very small and its only contribution to the sediments of the Bay occurs during periods of maximum runoff. 

The rocky areas to the north and south of the Bay, as well as the rocky outcrops on the eastern edge provide sediments to the Bay in two different forms. Analysis of the shell distribution of the Bay (Fig. 9) reveals the large part that is played in the composition of the Bay sediments by the shells and tests of the organisms living on and around these rocky areas. The weathering and decomposition of these rocky shorelines and outcrops must also make a substantial contribution to the sedimentary processes of the Bay.

Analysis of statistical wave data and wave refraction diagrams for Carmel Bay by Wallin [1968] showed that $90 \%$ of all deep water wave energy in the area emanated from the sector between west and north-northwest. This analysis also revealed that littoral transport would be southward from Carmel River Beach toward the canyon head, and eastward along Point Lobos toward the canyon head. This would require the only loss of sediments from the Bay to be via the submarine canyon itself.

Evidence of sediment loss via the canyon is presented by both Moritz [1968] and Wallin [1968]. They report the observation of several sandfalls on the north wall of the canyon head over a period of about 10 years. These sandfalls apparently run intermittently depending upon the sea conditions and the slope of the bottom. The sandfalls are reported to be largely dormant during the summer and fall, with activity increasing coincident with the flow of the Carmel River through the berm.

Shepard and Emery [1941, p. 100-102], in their studies of the head of the Carmel Submarine Canyon, noted a net fill of 
some 18 feet along the floor of the canyon in the inner section during the period 1934-1939. They concluded that this filling was so rapid that the canyon head would be filled within the next few years unless there was a large slide on the bottom. Shepard and Emery also noted that the old Carmel Bay survey of 1883 indicated shallower soundings than they obtained, suggesting a slide or slump had taken place during the intervening period. Moritz and Wallen observed a slump scar on the southeastern rim of the canyon while diving in this area, indicating slumping to be another mechanism by which sediment is transported to deeper water. 


\section{SUMMARY AND CONCLUSIONS}

Carmel Bay is a distinctive feature of the California coastline by virtue of its role as a sedimentary system primarily isolated from adjacent coastal sediment sources, and as the origin of the Carmel Submarine Canyon.

The recent marine sediments of the Bay consist primarily of moderate to poorly sorted sand and coarse silt deposits. One small area of very poorly sorted gravel is located in the northeastern sector of the Bay. Comparison of plots of mean grain-size vs. standard deviation and mean grain-size vs. skewness with similar plots obtained by Folk and Ward suggest that the sediments of the Bay are under the influence of some form of dynamic transport.

Fresh sedimentary materials are supplied to the Bay from several sources. The Carmel River is undoubtedly the prime supplier of terrigeneous sedimentary materials to the Bay, followed by erosion and weathering of the shoreline and offshore rocks, and terrigeneous materials supplied by San Jose Creek. The shells and tests of marine organisms also form a significant part of the sediments of the Bay. Considerable amounts of fine vegetable matter were also observed in several of the samples taken at or near the axis of the canyon.

The physical nature of the coastline immediately to the north and south of Carmel Bay effectively prohibits any littoral transport of sediments into the Bay, and wave 
refraction studies have shown that the sediments within the Bay tend to be transported by littoral drift to the head of the Carmel Submarine Canyon. Transportation into deeper water via the submarine canyon appears to be the only active mechanism for removal of sediments from the Bay. 


\section{SUGGESTIONS FOR FURTHER STUDY}

Until quite recently little marine geological research had been carried out within Carmel Bay. At present, Naval Postgraduate School (NPS) and San Jose State College, San Jose, California, studies are being conducted within the Bay concerning:

1. the marine geology of Carmel Bay (J. P. Simpson, NPS, in progress);

2. methods of sediment transport between the mouth of the Carmel River and the head of the Carmel Submarine Canyon (B. F. Howel 1, NPS, in progress);

3. sediment transport within Whalers Cove (L, Leopold, San Jose State College, in progress).

Further studies that would be useful in defining the marine environment of the Bay would include:

1. heavy mineral analysis of the sediments;

2. carbon, carbonate, and organic nitrogen analysis of the sediments;

3. current and water column structure determinations within the Bay. 



\section{APPENDIX A \\ Computer Data Card Formats}

For each sample:

Card 1: title card

Col 1-80 contain alphanumeric information to appear at the top of the output.

Card 2: identifier for sample

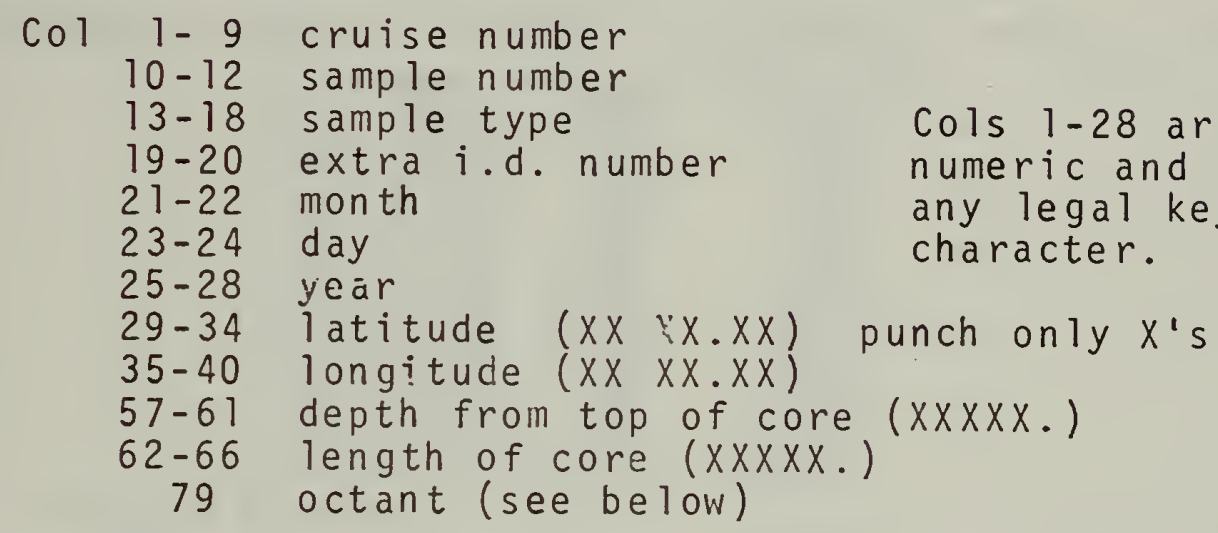

Card 3: sample detail cards

Col 4l-44 phi size (absolute value) F4.2 (decimal assumed) 45 sign of phi size (t or -)

50-56 fraction weight F7.4 (decimal assumed)

80 end of data flag

$=8$ if last phi size for this sample

$=9$ if last phi size for all samples

Coding for Octant of Geographic Position

Longitude East Longitude West

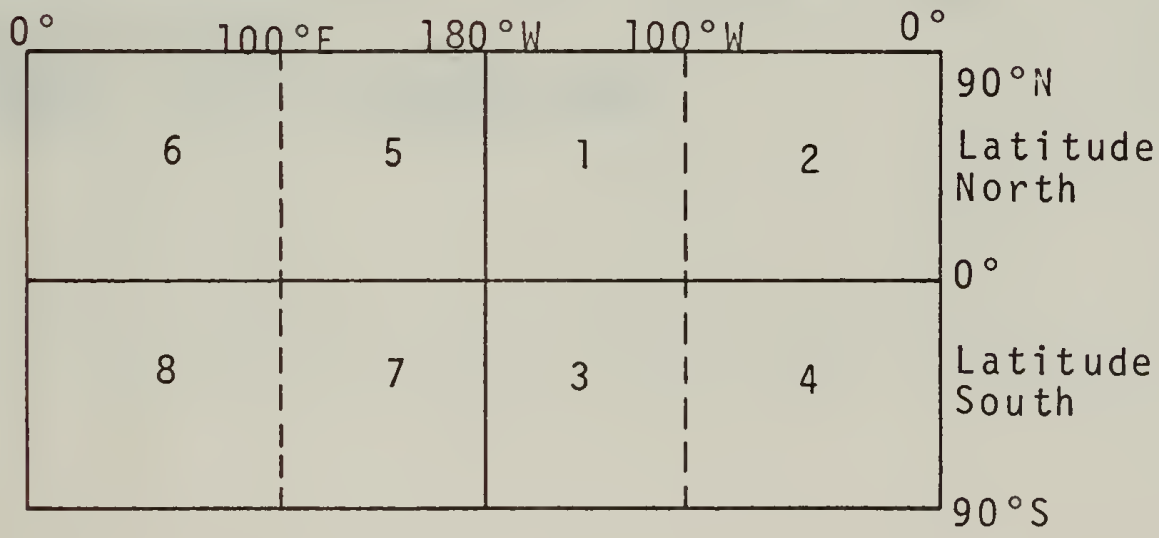





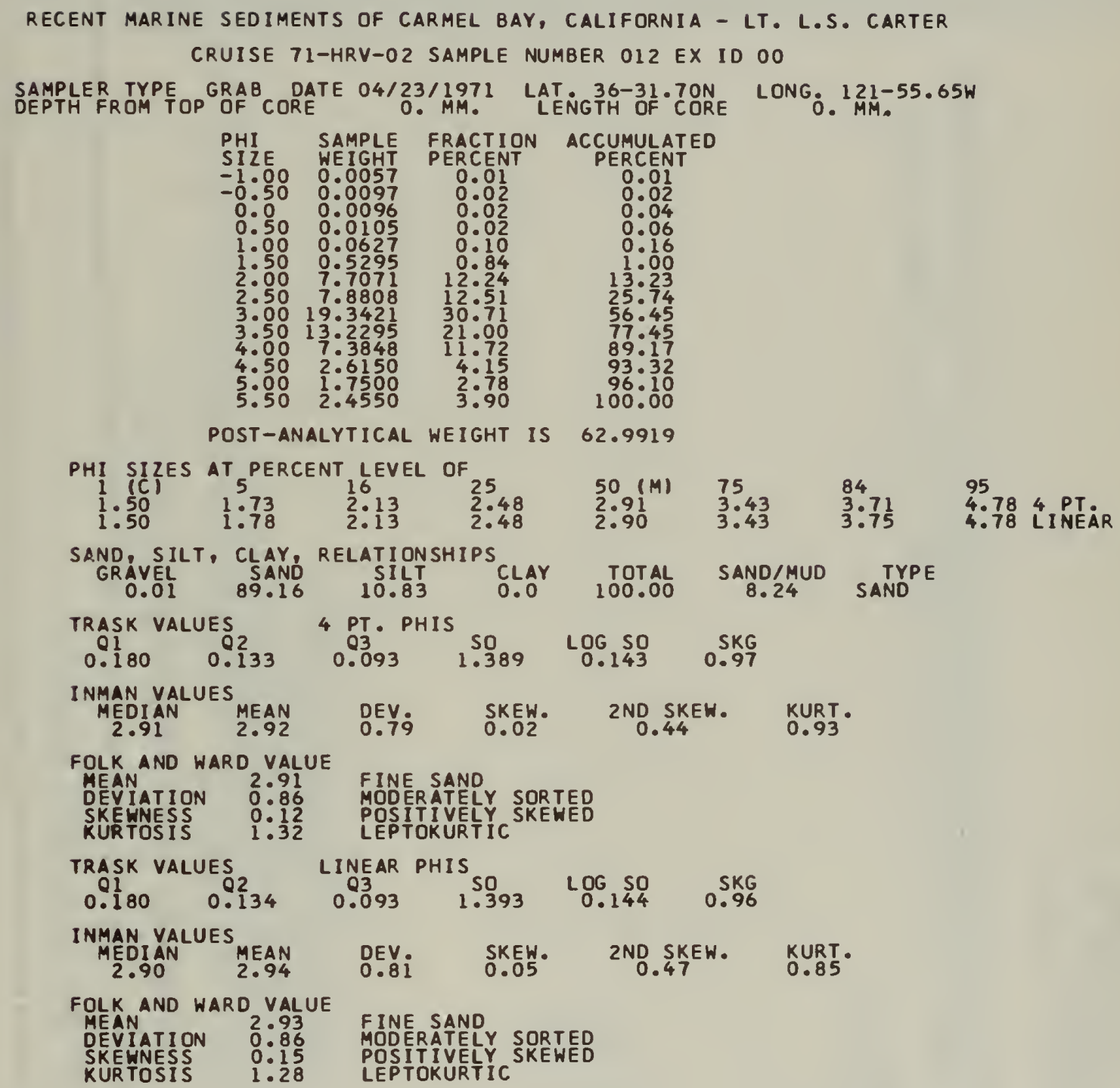




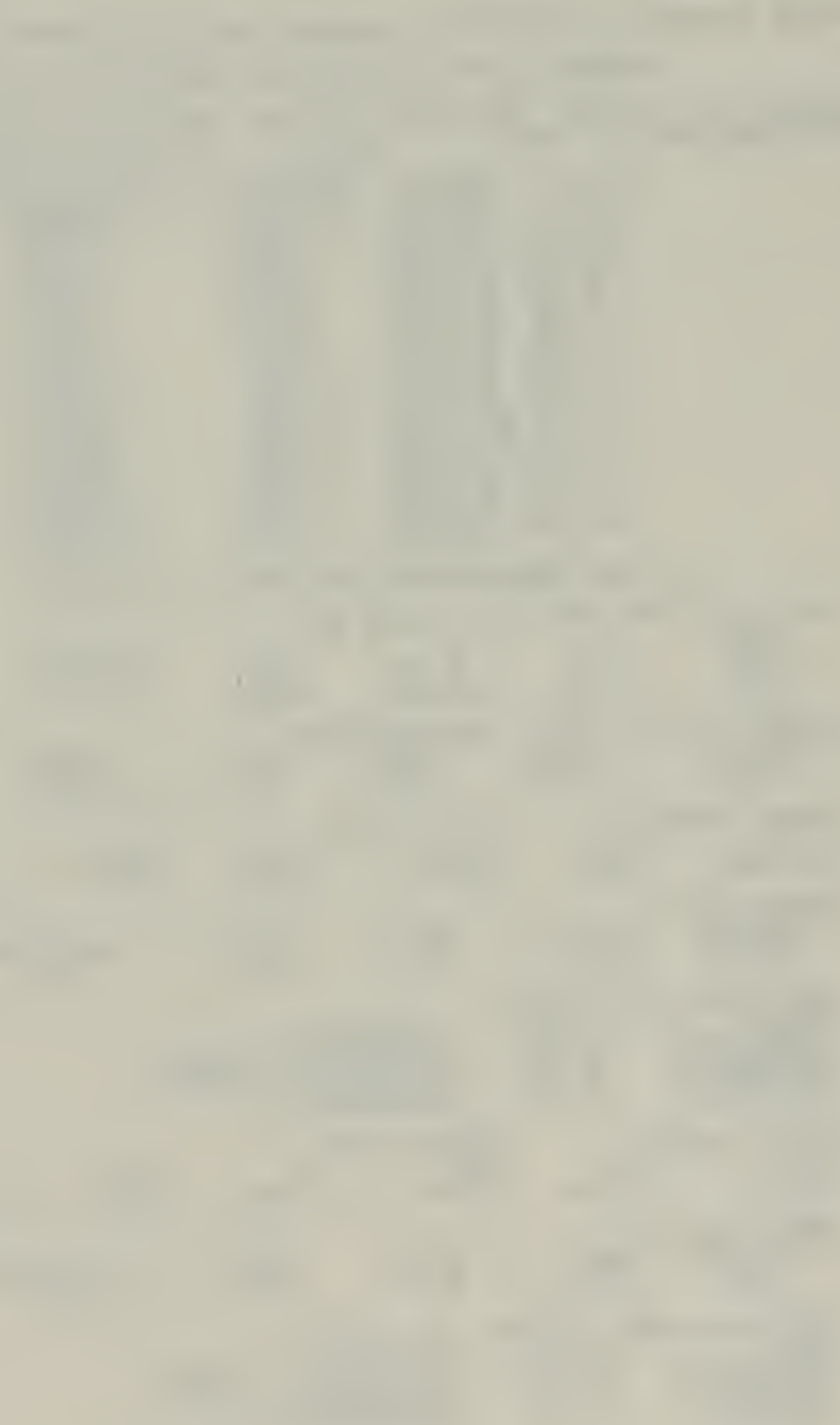


000000000000000000000000000000000000000000

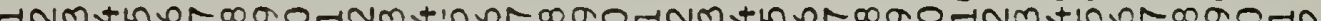

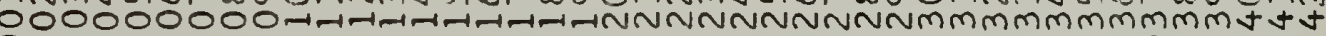
000000000000000000000000000000000000000000

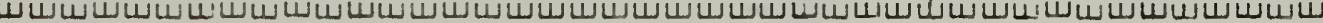

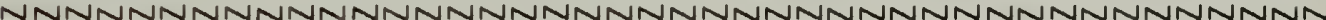

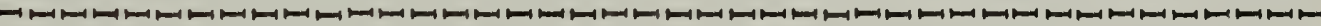

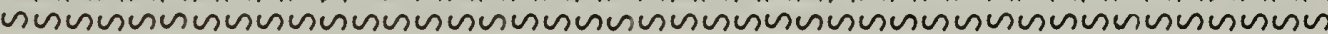

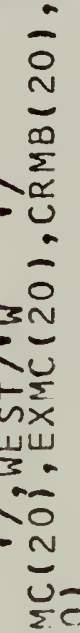

யเN

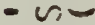

$>a$

$1-0$

भis

w-

NOUOOX

$\checkmark \sum N \sum 0$.

- $\alpha-n-1$

Ux 둥

-UUu

-mina

no $\not 2$ uा

-

$10 \ldots$

I-NMDO

1ヒー

วumaㅇ

oxdu-1

$\sim$ nat

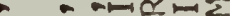

$\infty \longrightarrow N I$.

च - $0=-7000$

ज1 HOU -

I- -Nar

Q ZL NON

7 程乐

YIIUxut

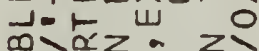

-000- OY

UZ $=0 \quad-x-$

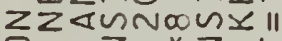

$z-* z^{\prime \prime}$

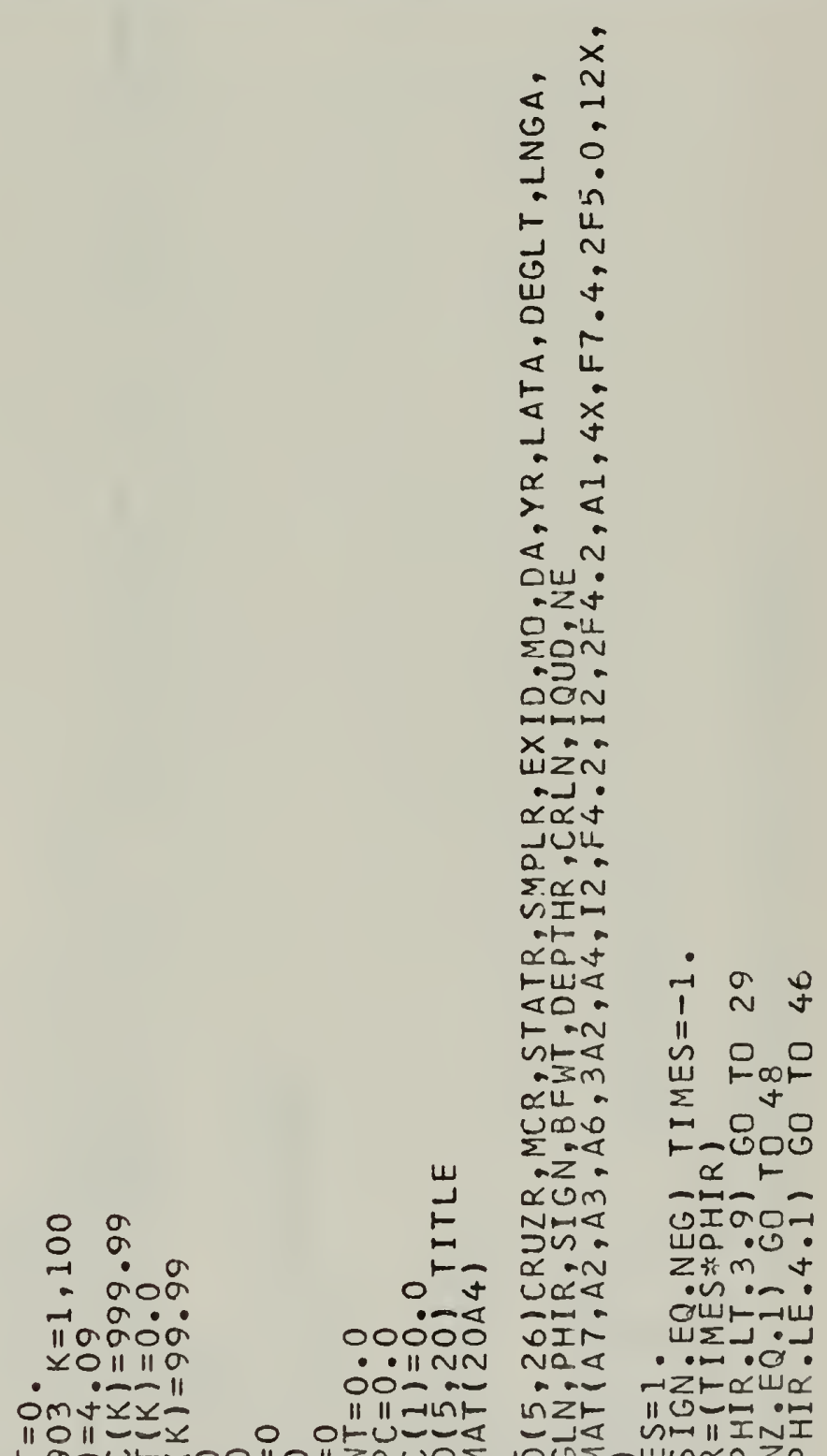

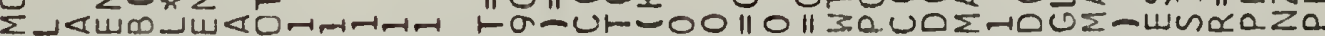

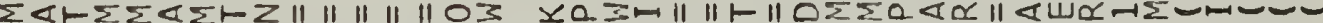

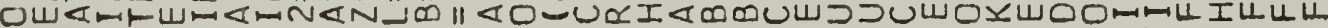

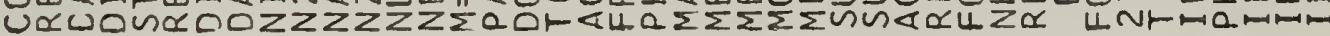

응

m

ONN 

000000000000000000000000000000000000000000000000

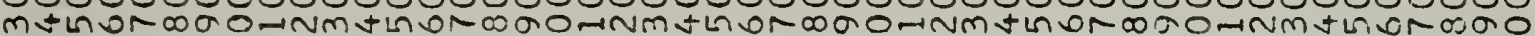

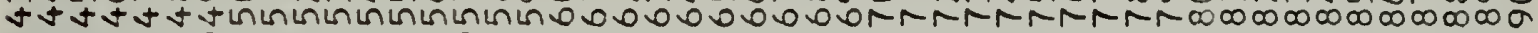
000000000000000000000000000000000000000000000000

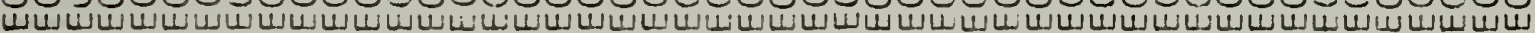

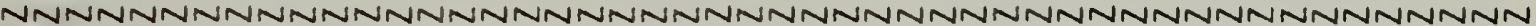

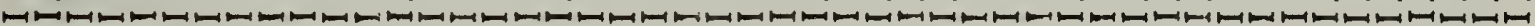

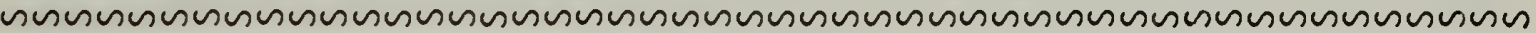

u

$\frac{1}{4}$

$\underset{1}{3}$

$\sim$

in

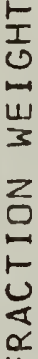

○

$0 \stackrel{\circ}{0}$

NO

$0_{m \in 0} \frac{\alpha}{\alpha}$

in

in -0

$0 \div \sum^{0}$

HO NO NO

OU ज- 3

$00 \propto ⿻ 0$

-

N-I $3 W$

-

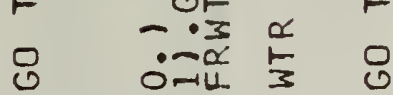

- 0 a

U.-

กा 1 (1) - म

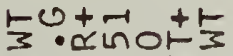

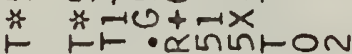

난

$\sum_{a}^{u}$

$\alpha$
$0 \frac{1}{\alpha}$
$0 \frac{1}{1}$
$\infty+5$
$1-\frac{1}{3}$

$\sigma+0 \quad$ uथ $\infty \cdot 3<\sigma 0$

cot $300<04$

$\|z \alpha-\| a \|$

NUUF 30 - no:3 J

LN

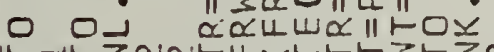

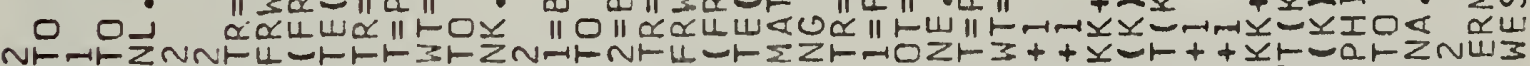

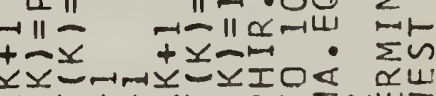
"Nト"

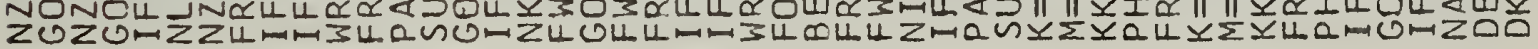
$\stackrel{1}{0}$
a
กำ
$\pm$
in

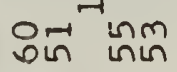
in
a 

000000000000000000000000000000000000000000000000

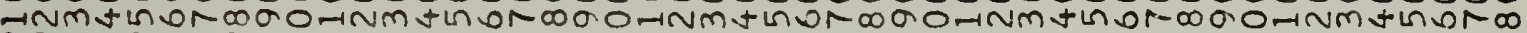

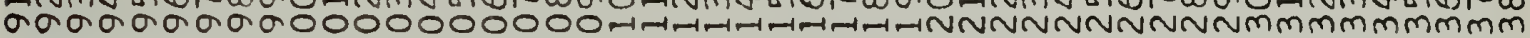

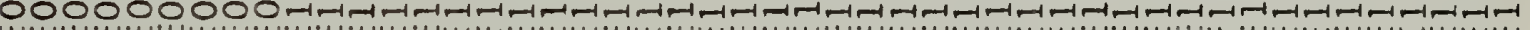

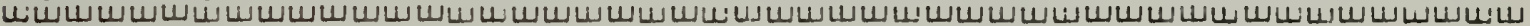

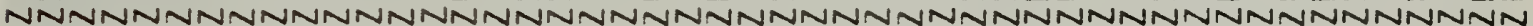

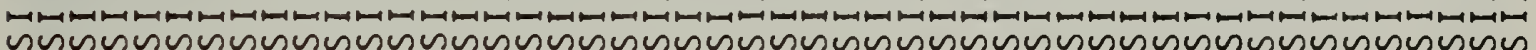

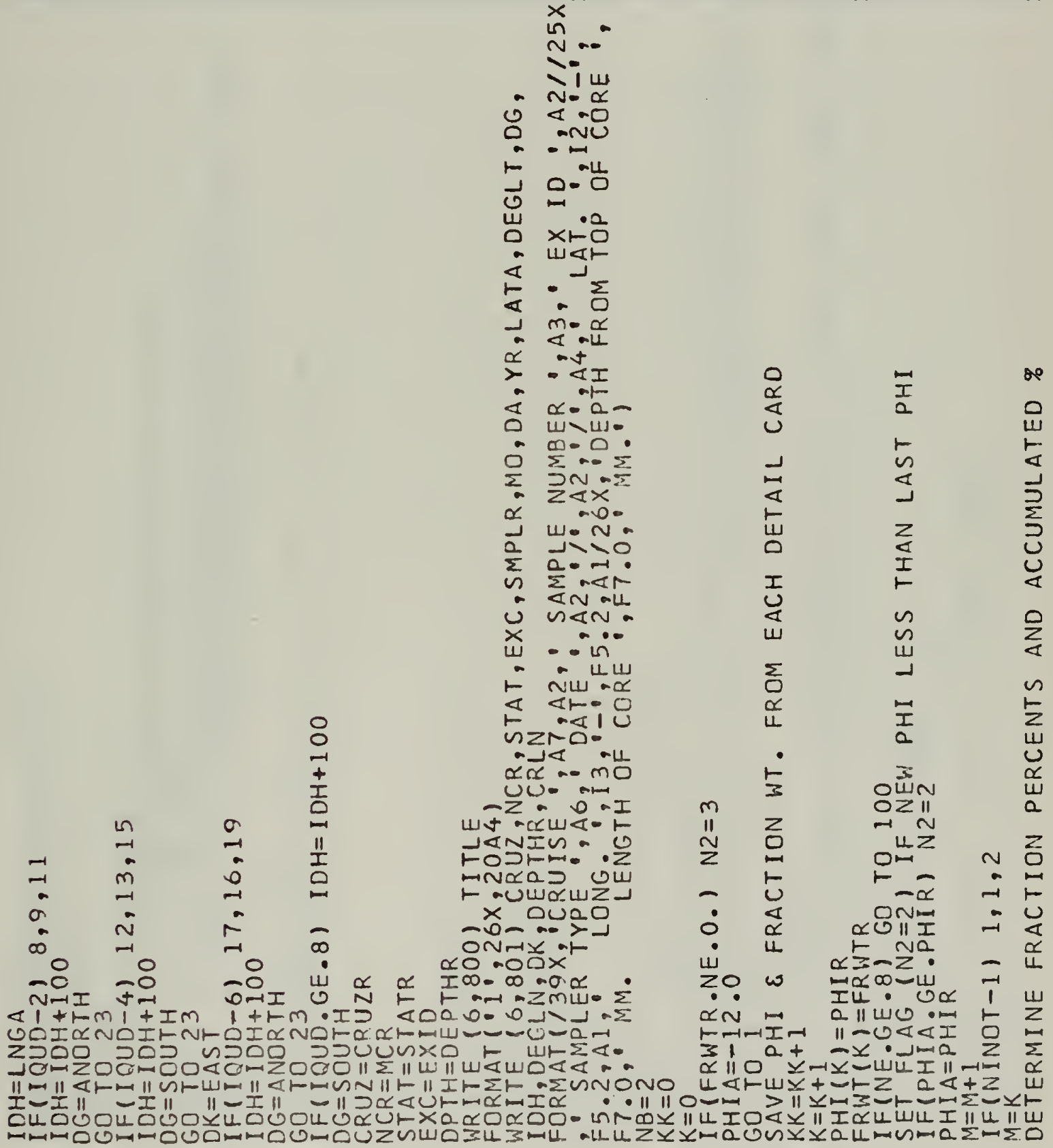

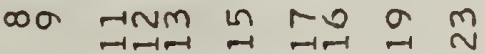

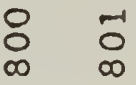

우

8

$\cup$

U 

000000000000000000000000000000000000000000000000

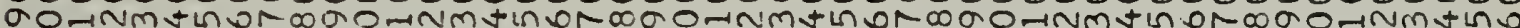

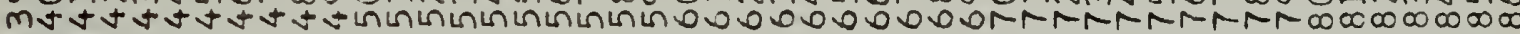

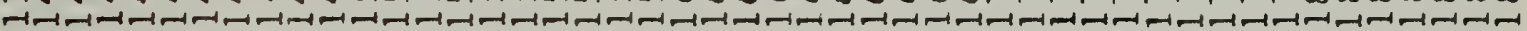

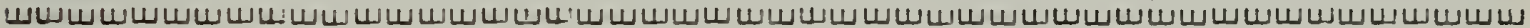

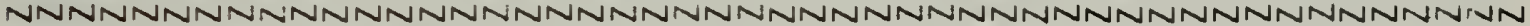

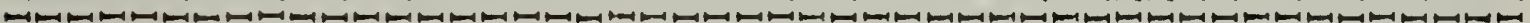

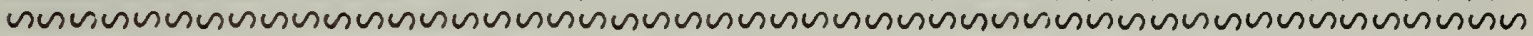

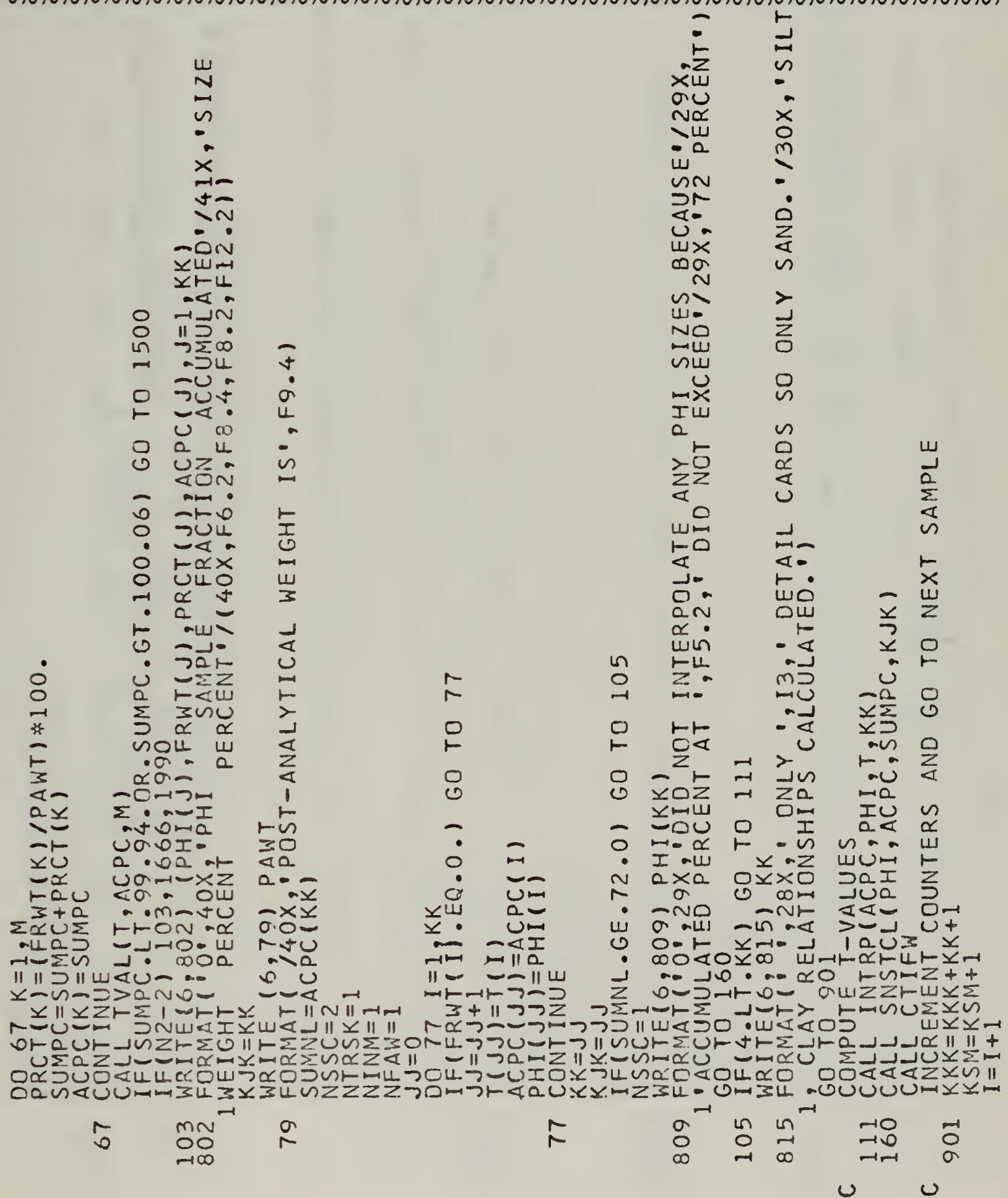



000000000000000000000000000000000000000000000000

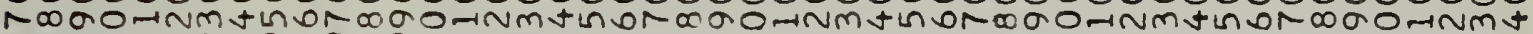

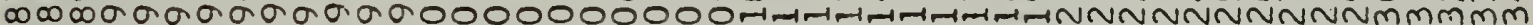

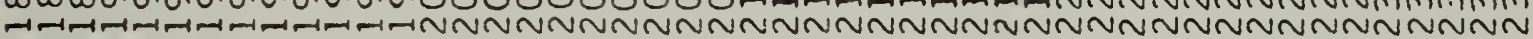

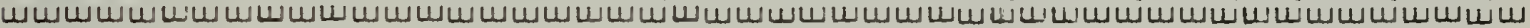

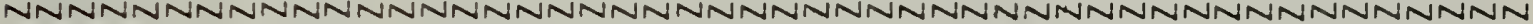

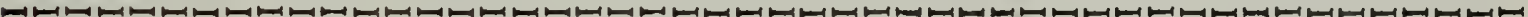

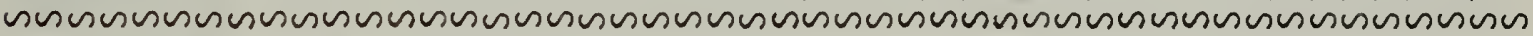
$\sum_{1}$

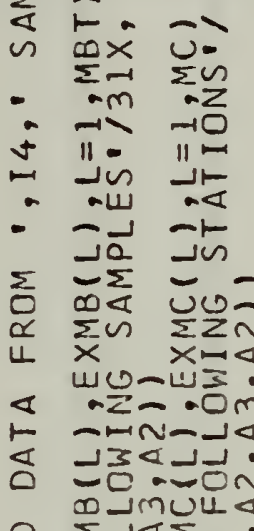
¿

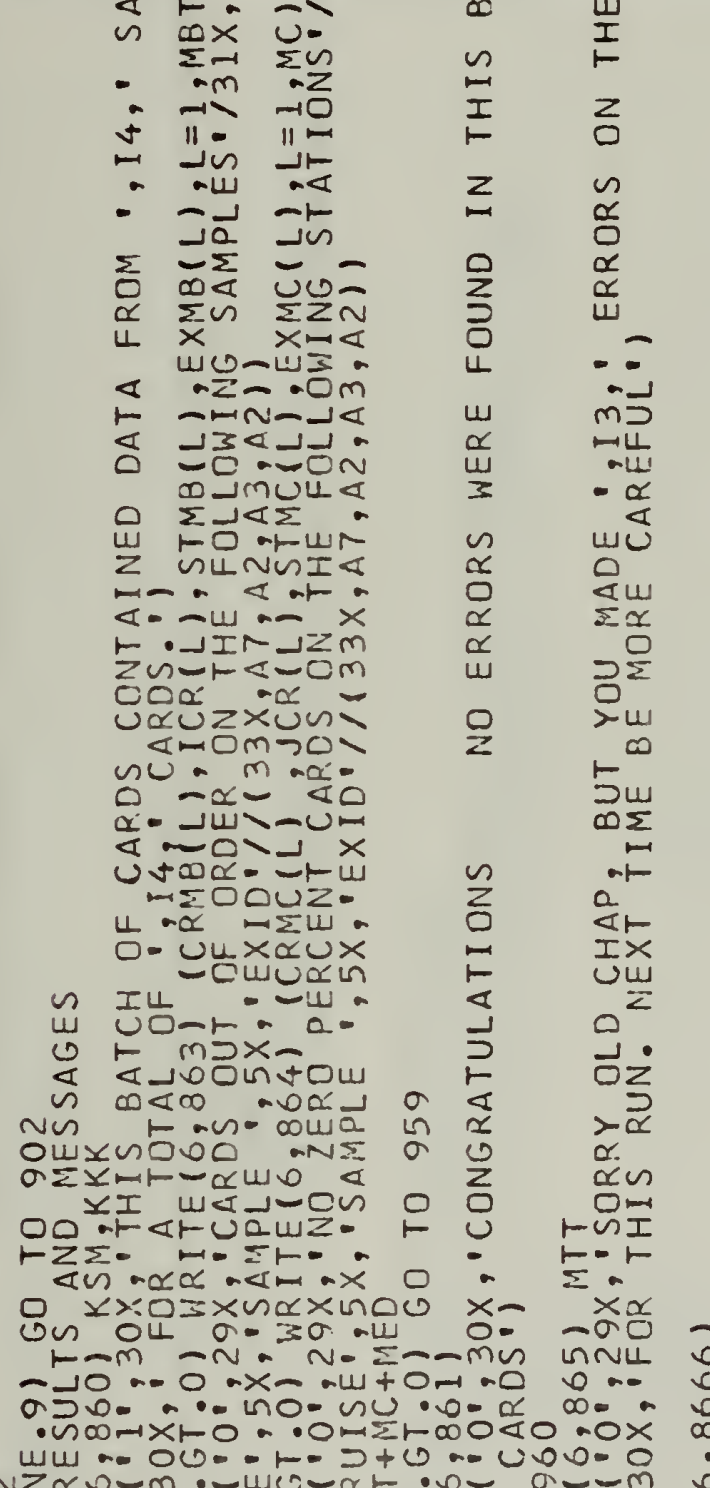

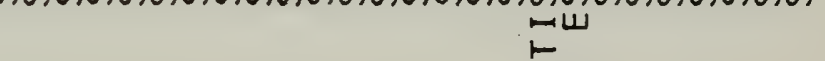

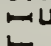

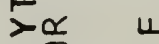
니 N Z <. $4 \frac{-5}{0}$ $-1$ งய

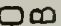
2 $-$

닐

$2 \sqrt{3}$

U

$\exists$

늠

$>$

ZF

$0 x$

مu

$x$

u

I

nu

I

U

$\frac{1}{0}$

U.

Im

$2 \infty$

ou

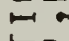

5

¿n

$\propto<$

43

5

$4 I$

ou

$\sim$ $\sum \frac{1}{3}$

$\alpha$

$\mathrm{ra}$

I-

$\underset{x}{ \pm} \frac{\pi}{x}$

12

- 7

$\sum_{0}$

47

20

0 um

F an

$y=4$

a $-N$

$1-1 \infty$

Шฉ丩

zगa

저웅

$\vdash>7 \sigma$

$4=4$

$\stackrel{\square}{a}=0$

แU⿺辶.

व $4 \sigma$

a a

F

I $2 N$

トேடİ

- ZIUJ

a $\times N$

$N \quad$ r

yo a

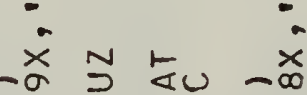

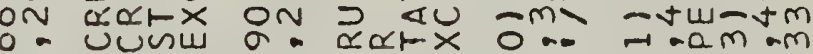

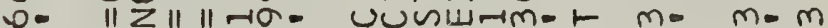

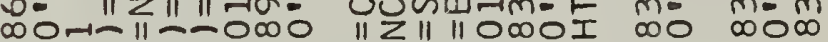

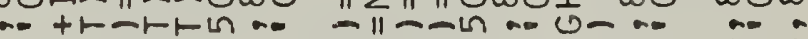

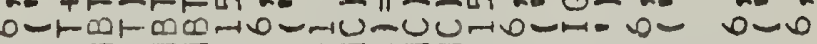
진 II-யюU⿺бZZト

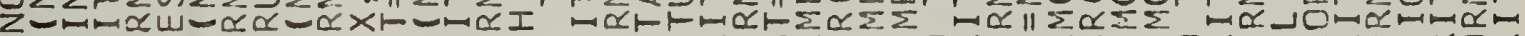
Zа

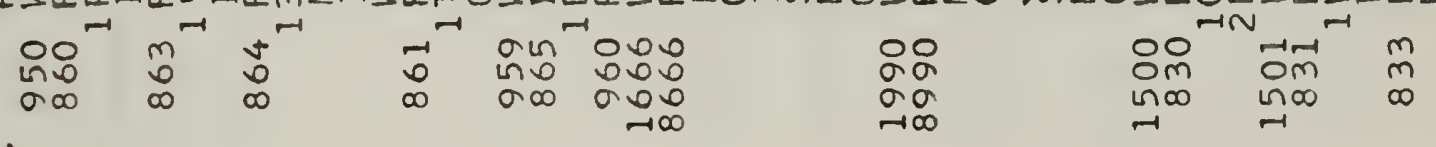



00000000000000000000000000000000000 o-nmitin

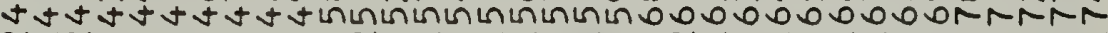

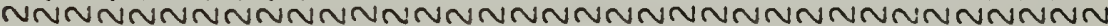

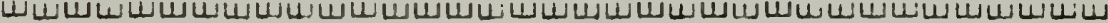

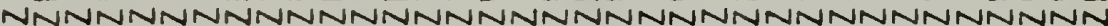

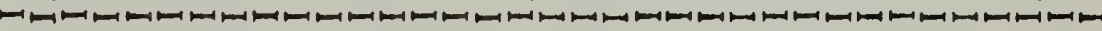

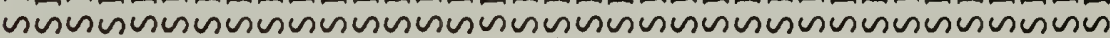

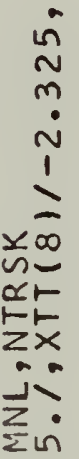

$\sum_{i=1}^{\infty}$

int

into

no

$\sim a n$

$Z_{\text {minin }}$

zina

- $<\cdot a$

$x-\frac{1}{2} 0^{\circ}:$

and mat

r- 2 an

$a z-\infty$

$m$ amt

InZN.

$0-1+20$

- - -

UMNOO

QI $m$

טan $\infty$

$<a-$.

¿nut

a $-\infty$

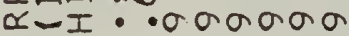

Łuami áááa

zo >......

-Uन-Lna

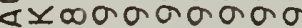

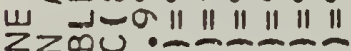

"OD I INANAN

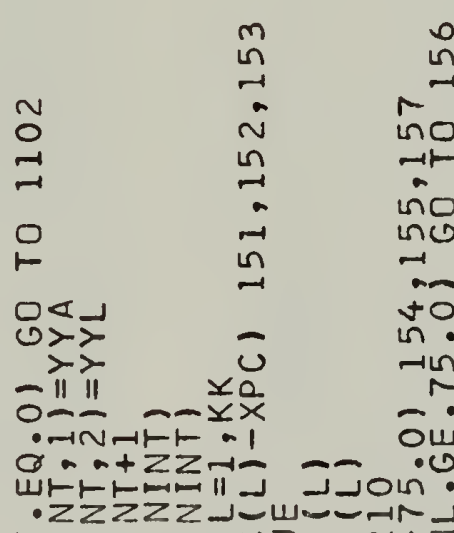

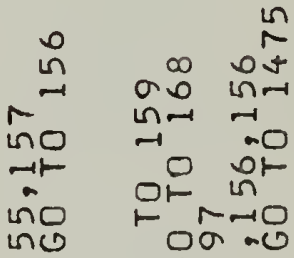

НM anama.

- 4

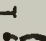

to

in.

Tin

-

०س

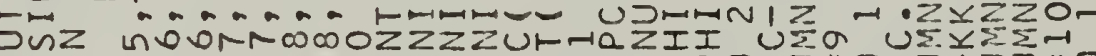

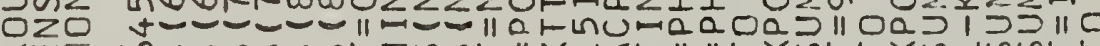

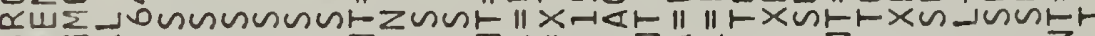

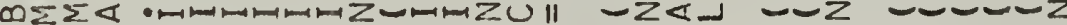

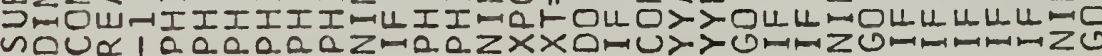
nou 1 $\rightarrow$

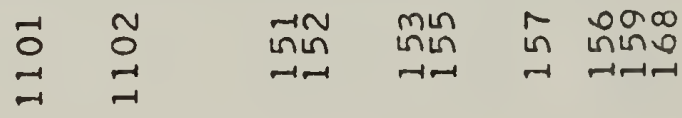



000000000000000000000000000000000000000000000000

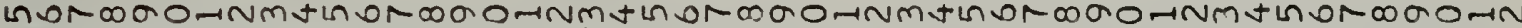

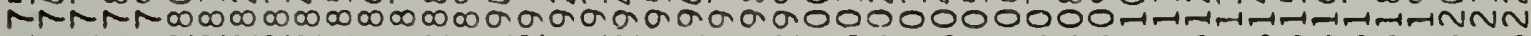

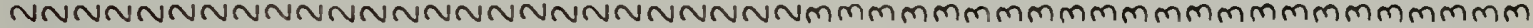

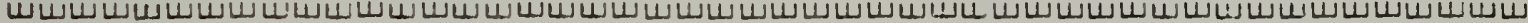

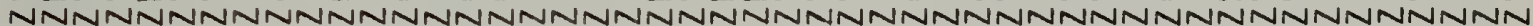

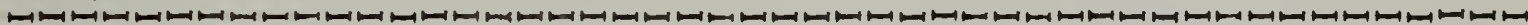

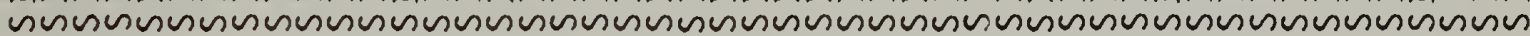

文

t

$\ddot{n-m}$

Nox

$x \times 1$

$-2-11 \pm$

$\ln +x$

$x \times x \times x$

$111=0$

$x \times x-\infty=$

$2 x \times x-2=$

니드

$1-2 \times x+1$

$4-\ldots-11 \mathrm{~m}$

in-mun

$0 \times x \times x \times=$

2 111 -

$\alpha-1-1,-1$ is $*$

$w \times x \times m+n$

$-2-1-1$

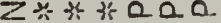

NmงーーーZ

$\rightarrow>1110$

익

Е111ニニュ

$-1-1 \times x \times<$

o $\quad 0$

$0-0-111$

$a \times x \times m+50$

$111 \times x \times 0$

a

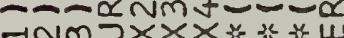

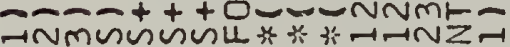

a $a$

$4-100$ - $10-1$

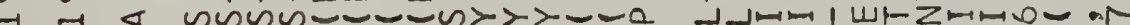

$\geq \geq a$

$\sum-1-1$

(1)

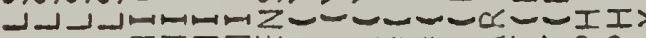

$x-1 Z=Z Z Z-1-x N z=\sum \sum \sum \sum \sum$

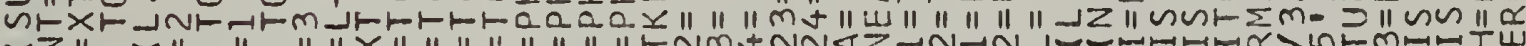

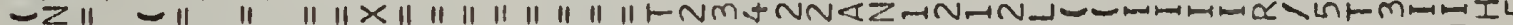

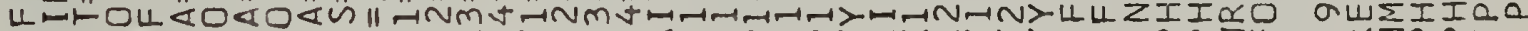

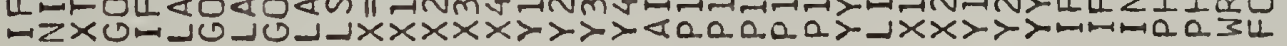

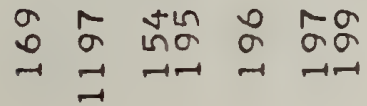

$\stackrel{\circ}{\sim}$

$m_{\infty}^{-n} \stackrel{n}{\sim} \underset{n}{n}$



0000000000000000000

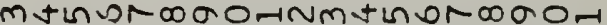
t t+t+t+thininin' + inin

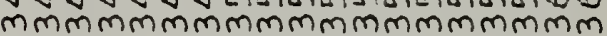

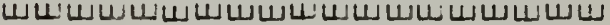
NNNNNNNNNNNNNNNNNNN

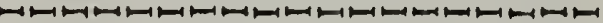
susunesusususususususususes

$\sin m a+\infty$ OnNoton moOmNaln

anamanam . . . .

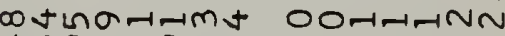
tinaninago minainatió

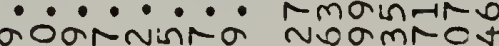
ONNmttat ...... n........ 000manN

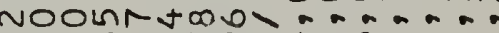

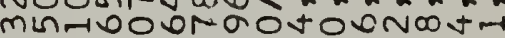
-..... nuamoot

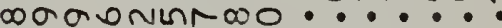
onnmutatathoón-inN

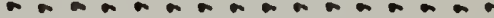

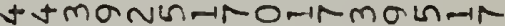
HtNaOMnDONINANDOM

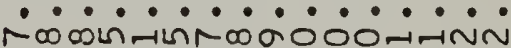
O-nmatatant.......... m......... mot

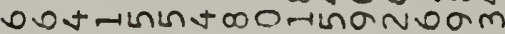

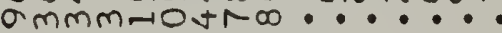

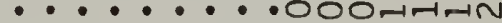

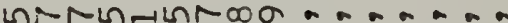

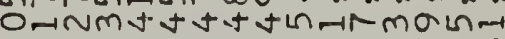

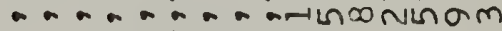

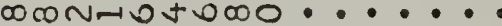
MNADORNOROOOHARN

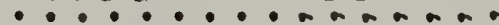
tontotromanoto ONO

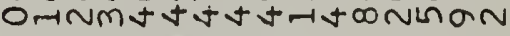

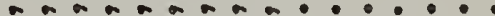
araGin-10R0000-m-N जnmtontolno ........... - * - * olnarmalóa

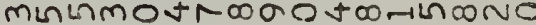
Oninmtatat.......

I $\sum$ Ootinnob00.......... NOIn-1000ttmnotoñm

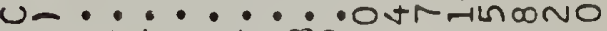
0matatmatocoa.......

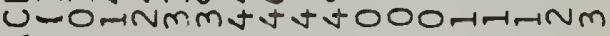

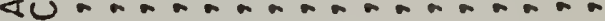

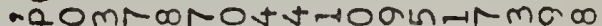

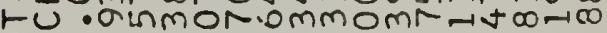

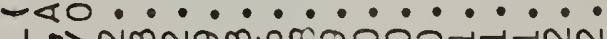
S$>$ ar a...........

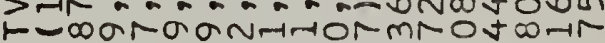

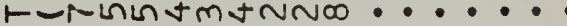

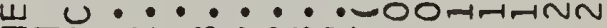

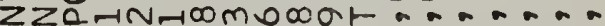

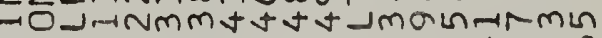

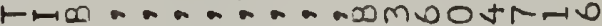

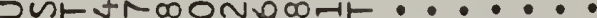
ठZ OINGOनOM OOHनHNN Qw].........

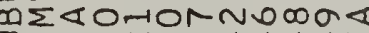

DHWनNMmttt+U n०o

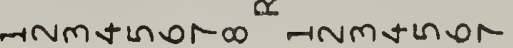





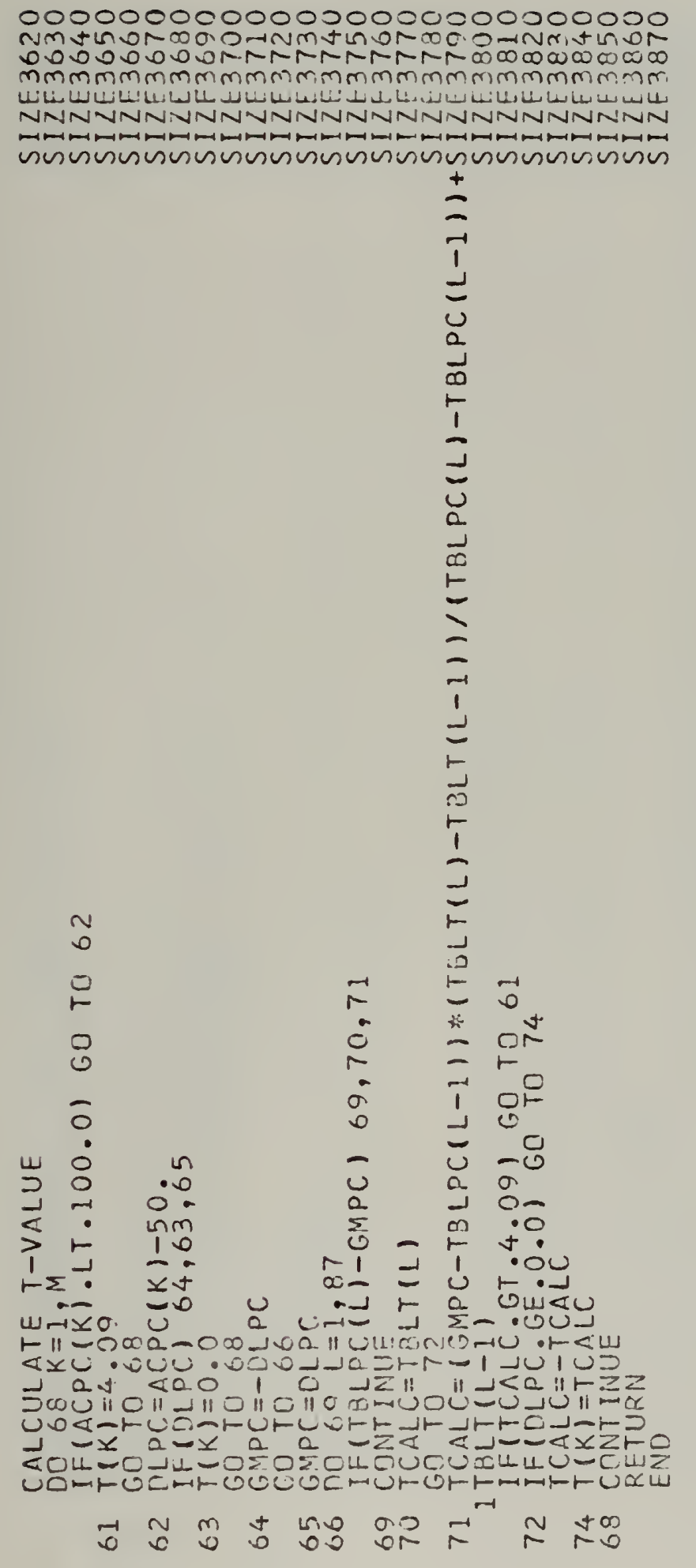

00000000000000 na dornmintinor-malon mminmmmmmmmnits

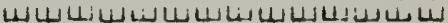
NNNNNNNNNNNNN

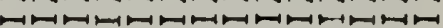

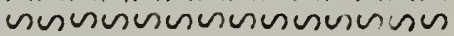

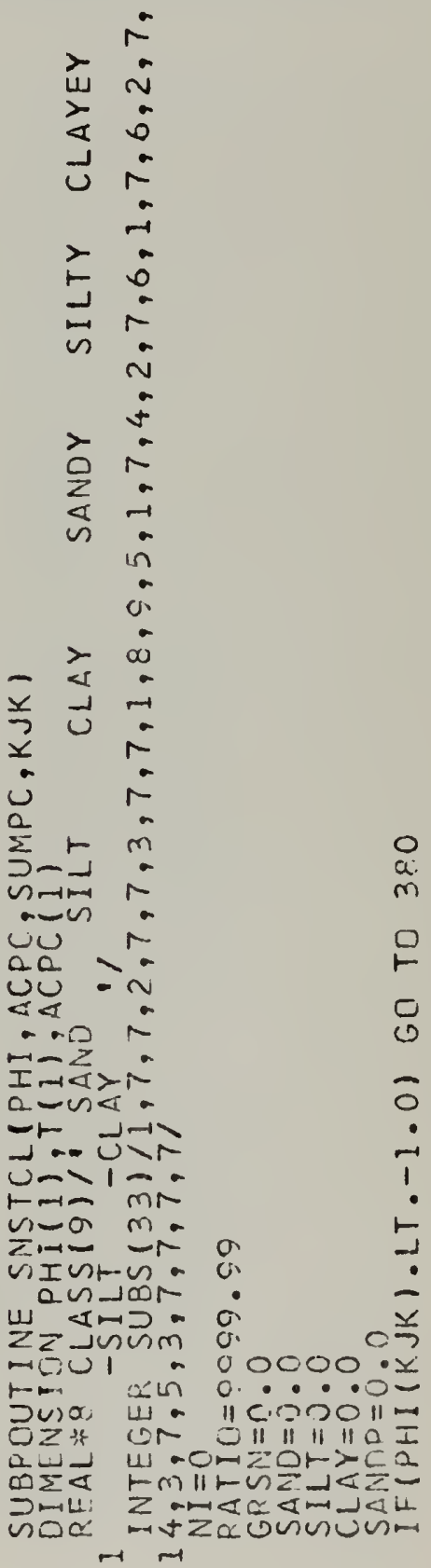



000000000000000000000000000000000000000000000000

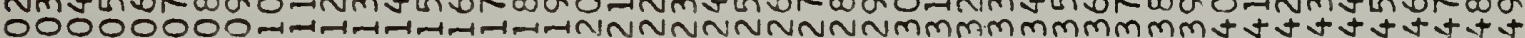

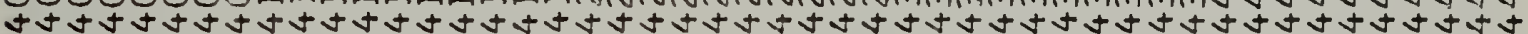

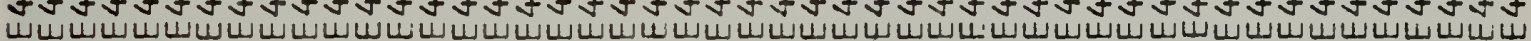

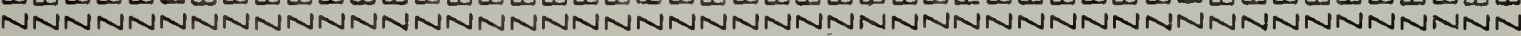
nü

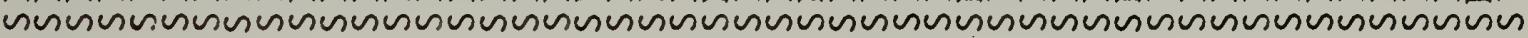

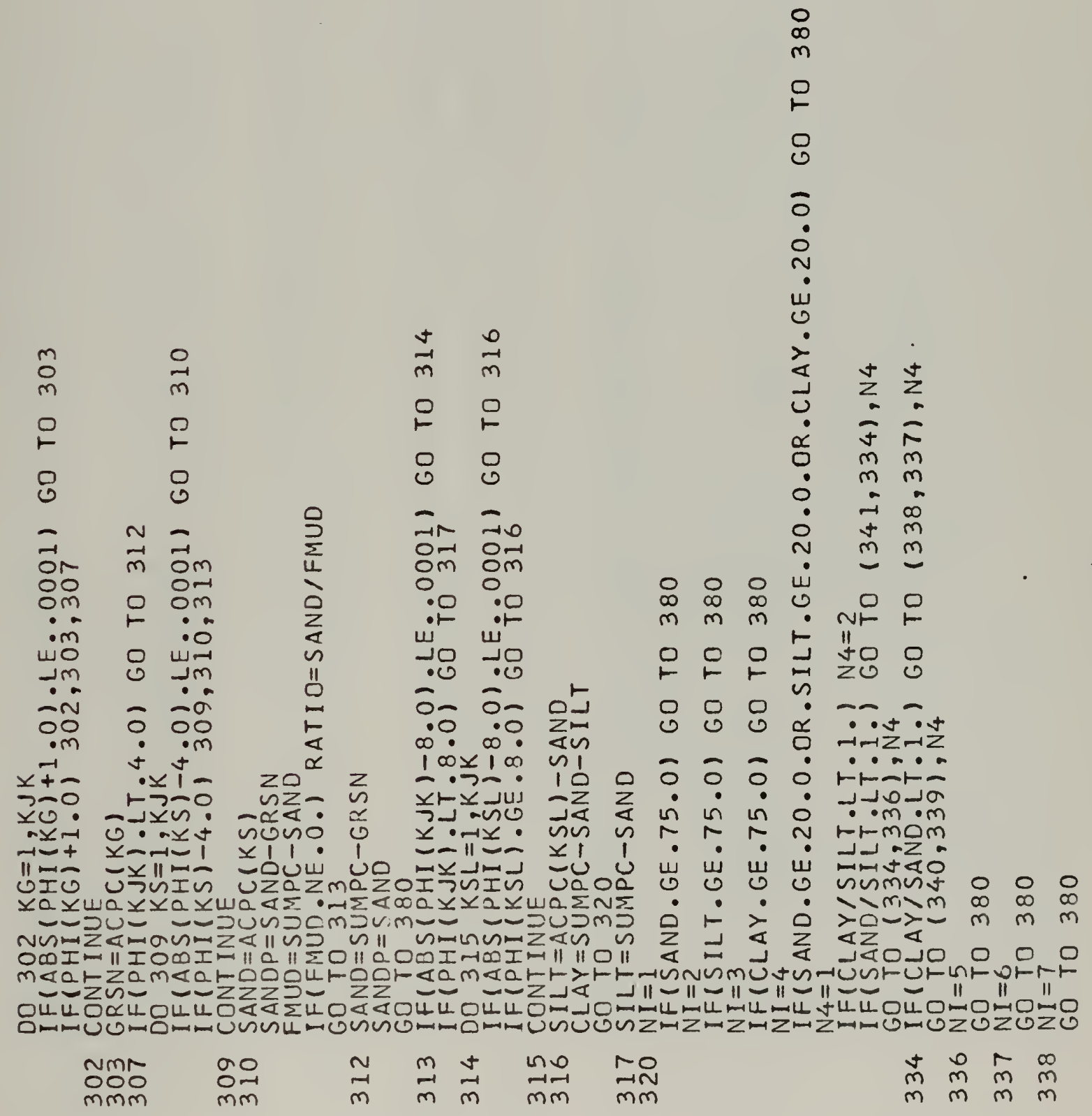



O0000000000000000

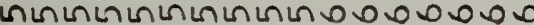

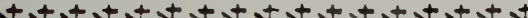

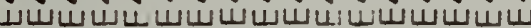
NNNNNNNNNNNNNNNNN กอง

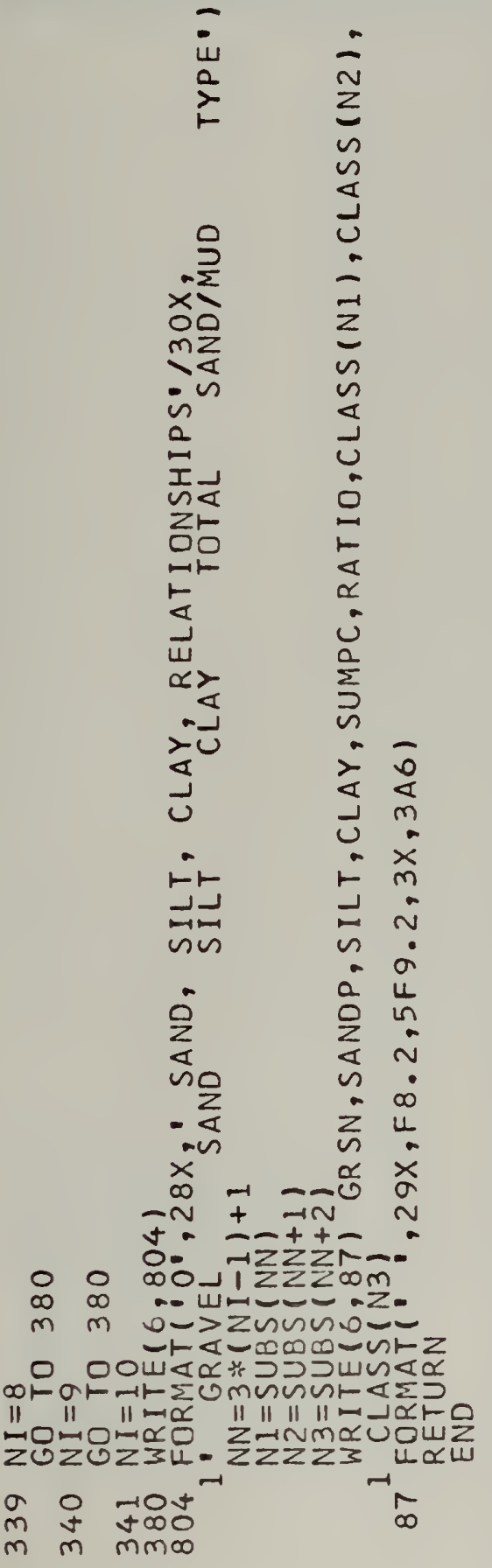

00000000000000000000000 ODON-N-N-NMN $\infty 000000000000$

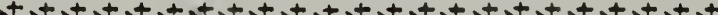

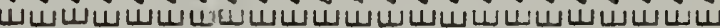
NNNNNNNNNNNNNNNNNNNNNNN

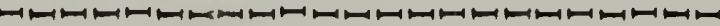
susususususunususususususususes

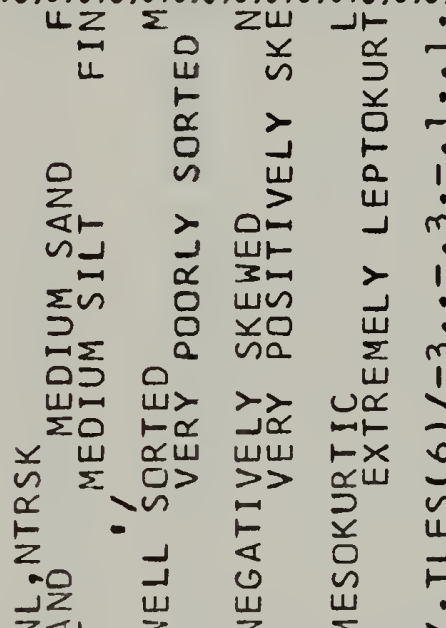
z<r $\leq \quad z$ In] ทีயง

an

৩๘ய

ज⿺乚

vox

ZU⿺

$-00>0 \alpha$

żப<ய०

⿺辶

un $\cup \alpha \backslash \omega>$

$z 0$ o $>>$

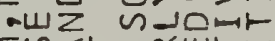

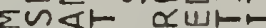

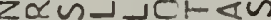

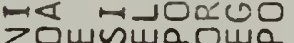

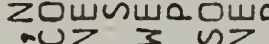

$-\cup z$

No-uzz

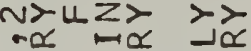

$\infty ய>ய w$ 뚜

$\rightarrow \alpha>0>$

nニய>

zn> $>0>00 \backslash<$

UII

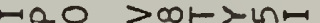

$-N \quad-\alpha-\sqcap \alpha$

Un⿺ -0யニ

$x z$

凹n

Zक्ट

แய

$\rightarrow N O$

$$
0-15 x
$$

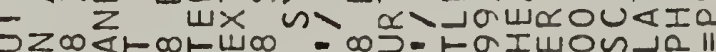
我

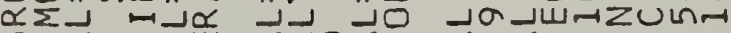

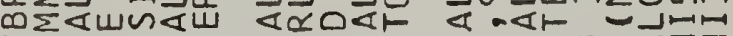

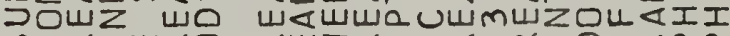

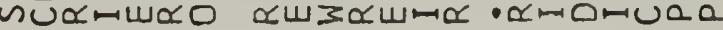
IN $\rightarrow N$ HN $\rightarrow N$, 

000000000000000000000000000000000000000000000000 O-NMm बनन2

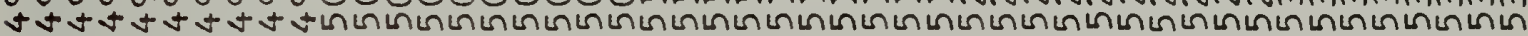

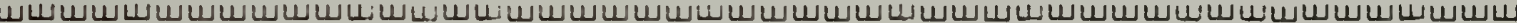

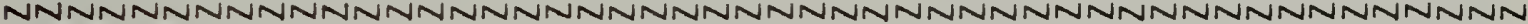

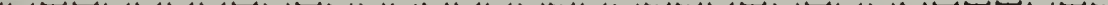

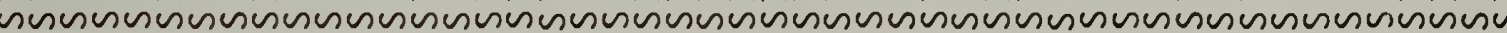

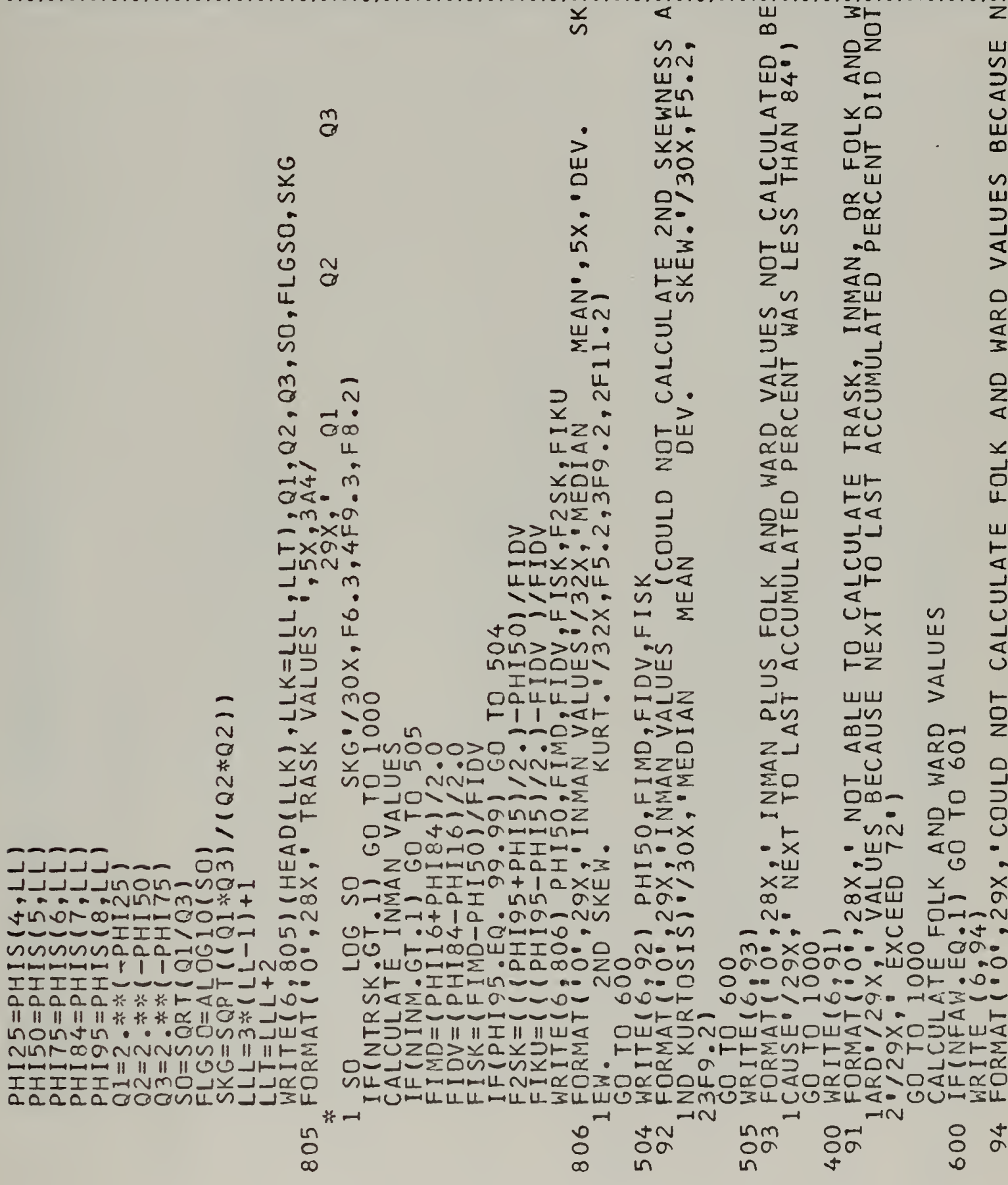



000000000000000000000000000000000000000000000000

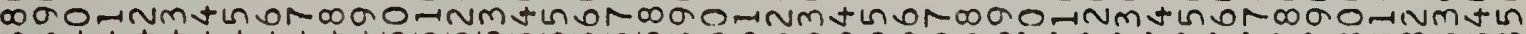

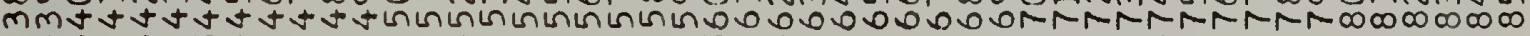

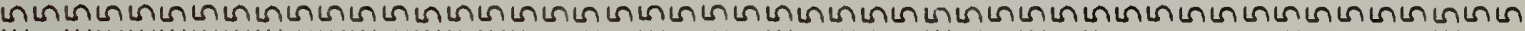

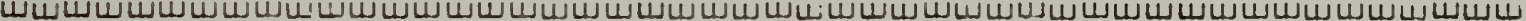

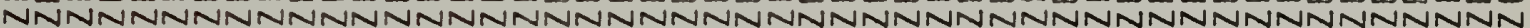

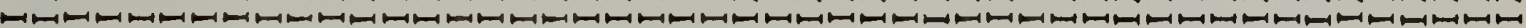

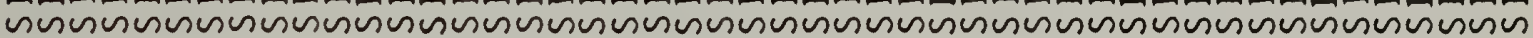

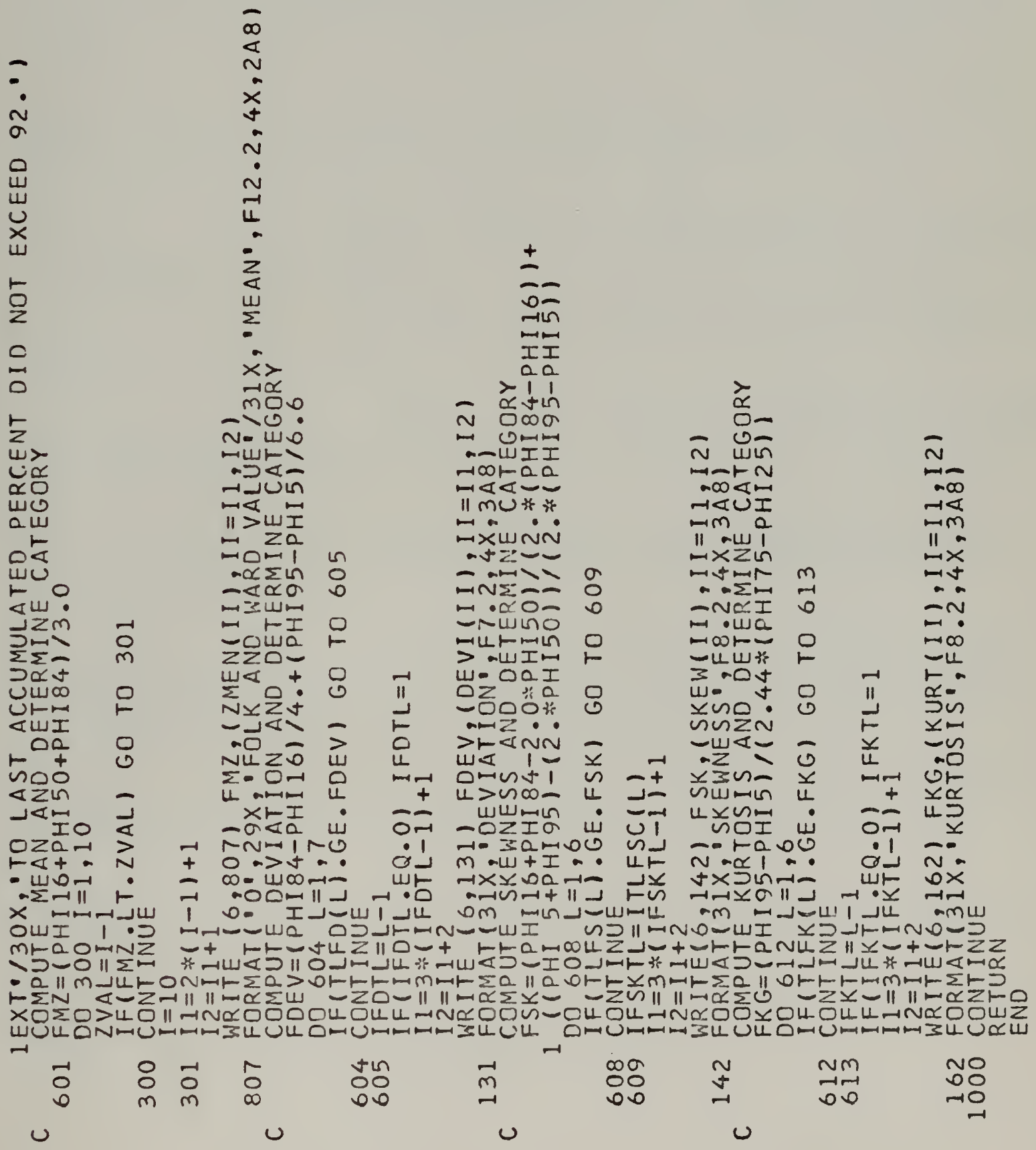



1. Beal, C. H. 1915. The Geology of the Monterey Quadrangle. M.A. Thesis, Leland Stanford Junior University, Palo Alto$\mathrm{Ca} .88 \mathrm{p}$.

2. Bowen, 0. E. 1965. Point Lobos, a Geologic Guide. Cal. Div. Mines and Geology Mineral Inf. Service. 18(4):60-67.

3. California State Department of Water Resources. 1969. Carmel River Basin Water Quality Investigation. Central Coastal Regional Water Quality Control Board, San Luis Obisbo, Ca. $46 \mathrm{p}$.

4. Collias, E. E., M. R. Rona, D. A. McManus, and J. S. Creager. 1963. Machine Processing of Geological Data. Univ. Washington Dep. Oceanogr. Tech. Rep. 87. 119 p.

5. Dinger, C. 1970. Computer Program in Oceanography. Publication $C-5$ (2nd Revision). National Oceanographic Data Center, Washington, D.C. $143 \mathrm{p}$.

6. Folk, R. L. 1968. Petrology of Sedimentary Rocks. Hemphill's, Austin, Texas. $170 \mathrm{p}$.

7. Folk, R. L., and W. C. Ward. 1957. Brazos River Bar: A Study in the Significance of Grain Size Parameters. J. Sediment. Petrol. 27( 1$): 3-26$.

8. Griffin, P. A. 1969. Heavy Mineral Investigaticn of Carmel Bay Beach Sands. M.S. Thesis, Naval Postgraduate School, Monterey, $\mathrm{Ca}$. $50 \mathrm{p}$.

9. Judge, C. W. 1970. Heavy Minerals in Beach and Stream Sediments as Indicators of Shore Processes between Monterey and Los Angeles, California. U.S. Army Coastal Engr. Research Center, Tech. Memo. No. 33, Washington, D.C. 44 p.

10. Krumbein, W. C., and F. J. Pettijohn. 1938. Manual of Sedimentary Petrography. Appleton-Century-Crofts, Inc., New York. 549 p.

11. Krumbein, W. C., and L. L. Sloss. 1963. Stratigraphy and Sedimentation, $2 d$ ed. W. H. Freeman and Co., San Francisco, Ca. $660 \mathrm{p}$.

12. Lawson, A. C. 1893. The Geology of Carmelo Bay. Bull. Dept. Geol., Univ. of Ca., Berkeley. 1:1-59. 

13. Martin, B. D. 1964. Monterey Submarine Canyon, California: Genesis and Relationship to Continental Geology. PhD Dissertation, Univ. of S. Ca., Los Angeles. 249 p.

14. Moritz, C. A., Jr. 1968. A Descriptive Survey of the Head of the Carmel Submarine Canyon. M.S. Thesis, Naval Postgraduate School, Monterey, Ca. $82 \mathrm{p}$.

15. Nili-Esfahani, A. 1965. Investigation of Paleocene Strata, Point Lobos, Monterey County, Ca. M.A. Thesis, Univ. of Ca., Los Angeles. $228 \mathrm{p}$.

16. Shepard, F. P. Submarine Geology, 2d ed. Harper and Row, New York. $557 \mathrm{p}$.

17. Shepard, F. P., and K. O. Emery. 1941. Submarine Topography off the California Coast: Canyons and Tectonic Interpretation. Geol. Soc. Amer. Spec. Paper 31. $171 \mathrm{p}$.

18. Sverdrup, H. U., N. W. Johnson, and R. H. Fleming. 1942. The Oceans, Their Physics, Chemistry, and General Biology.

Prentice-Hall, Inc., Englewood Cliffs, N. J. 1087 p.

19. U.S. Coast and Geodetic Survey. 1971. Tide Tables, High and Low Water Predictions, 1971, West Coast North and South America including the Hawaitan Islands. U.S. Government Printing Office, Washington, D.C. 226 p.

20. Wallin, S. R. 1968. The Sediments in the Head of the Carmel Submarine Canyon. M.S. Thesis, Naval Postgraduate School, Monterey, Ca. $98 \mathrm{p}$.

21. Zardeskas, R. A. 1971. A Bathymetric Chart of Carmel Bay, Ca. M.S. Thesis, Naval Postgraduate School, Monterey, Ca. 108 p. 

No. Copies

1. Defense Documentation Center

Cameron Station

A lexandria, Virginia 22214

2. Library, Code 0212

Naval Postgraduate School

Monterey, California 93940

3. Professor R.S. Andrews, Code 58Ad

Department of Oceanography

Naval Postgraduate School

Monterey, California 93940

4. Department of Oceanography, Code 58

Nava 1 Postgraduate School

Monterey, California 93940

5. LCDR C.K. Roberts, USN

Department of Oceanography, Code $58 \mathrm{Rb}$ Naval Postgraduate School

Monterey, California 93940

6. LT R.A. Zardeskas, USN

Tactical Electronic Warfare Squadron 129

NAS Whidbey Is I and

Oak Harbor, Washington 98277

7. LT L.S. Carter, USN

COMFAIRADAK Staff

U.S. Naval Station

F.P.0. Seattle, Washington 98791

8. Mr. Thompson J. Hudson

Pt. Lobos

Carmel, California 93921

9. Mr. Frederick A. Meyer

Environmental Resources Section

Supervisor, Dept. of Parks and Recreation

State of California - Resources Agency

P.0. Box 2390

Sacramento, California 95811 

No. Copies

10. Office of Naval Research Code $480 \mathrm{D}$

Arlington, Virginia 22217

11. Point Lobos State Reserve Carme 1, California 93921

Attn: Mr. D. Rich

12. Dr. Francis P. Shepard

Scripps Institute of Oceanography

University of California at San Diego

La Jolla, California 92038

13. LT J.P. Simpson, USN

Naval Postgraduate School, SMC \#1105

Monterey, California 93940

14. Mr. Earl Smith

Director, Monterey County Park Dept.

P.0. Box 367

Salinas, California 93901

15. Professor W. C. Thompson, Code 58Th

Department of Oceanography

Naval Postgraduate School

Monterey, California 93940

16. Mr. Lawrence Leopold

Department of Geology

San Jose State College

San Jose, California

17. Dr. Pat Wilde

Hydraulic Engineering Lab

University of California

Berkeley, California

18. Oceanographer of the Navy

The Madison Building

$732 \mathrm{~N}$. Washington

Alexandria, Virginia 22314

19. LT B. F. Howe 11

Naval Postgraduate School, SMC \#1028 Monterey, California 93940 

Unclassified

Security Classificalion

DOCUMENT CONTROL DATA.R \& D

(Securify classilication of illle, body of abstract and indexing annotation must be ontered when the overall report is classilied) ORIGINATING ACTIVITY (COROPAle author)

Naval Postgraduate School Monterey, California 93940

2a. REFORT SECURITY CLASSIFICATION

Unclassified 2b. GROUP

\section{RECENT MARINE SEDIMENTS \\ of \\ CARMEL BAY, CALIFORNIA}

4 oescaiptive notes (Type of eepori and, inclusive dates)

Master's Thesis; December 1971

AUTHORIS) (First name, middlo initial, last namo)

Lee Scott Carter

Lieutenant, United States Navy

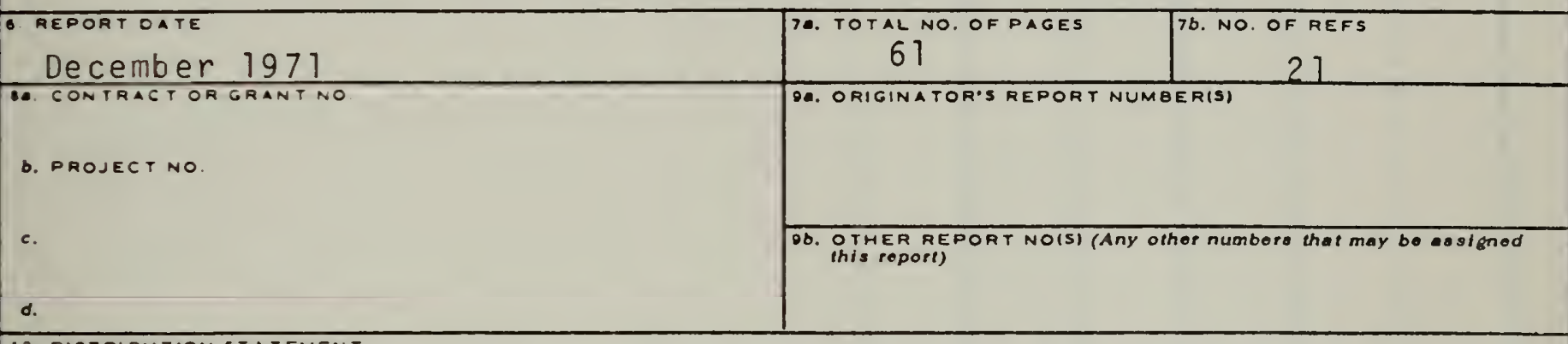

Approved for public release; distribution unlimited.

11. SUPPLEMENTAAY NOTES

Naval Postgraduate School

Monterey, California 93940

Fifty-six sediment samples were collected within Carmel Bay for textural analysis to determine their statistical properties. The sediments found within the Carmel Submarine Canyon consist, for the most part, of poorly to very poorly sorted very fine sand and coarse silt. The shelf area surrounding the canyon is primarily comprised of moderately to very poorly sorted sand, with a small area of very poorly sorted gravel in the northeastern section of the Bay. Consideration of textural parameters such as mean size, standard deviation, and skewness suggest that the sediments of the Bay are under the influence of dynamic sediment transport mechanism. The Bay appears to be a sedimentary system primarily isolated from adjacent coastal sediment sources, with the major sources of sedimentary deposits being terrigeneous debris from the carmel River, erosion and weathering of the local coastline and offshore rocks by wave and weather, and the shells and tests of numerous calcareous marine organisms. Movement of sediments by slumping and gravity sliding down the Carmel submarine Canyon appears to be the only form of sediment removal within the Bay. 

Carme 1 Bay

Carme 1 Submarine Canyon

Sediment Analys is

Marine Sediments 




Thesis

C27373 Carter

c. 1 .

133020

Recent marine sediments of Carmel Bay, California. 


\section{thesC27373}

Recent marine sediments of Carmel Bay, C

III

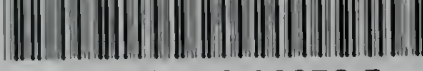

32768002092785 DUDLEY KNOX LIBRARY 